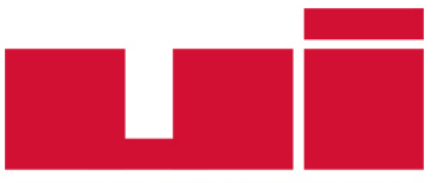

ULUUSLARARASTILIŞKiLER

Akademik Dergi

Yayın ilkeleri, izinler ve abonelik hakkında ayrıntılı bilgi:

E-mail: bilgi@uidergisi.com.tr

Web: www.uidergisi.com.tr

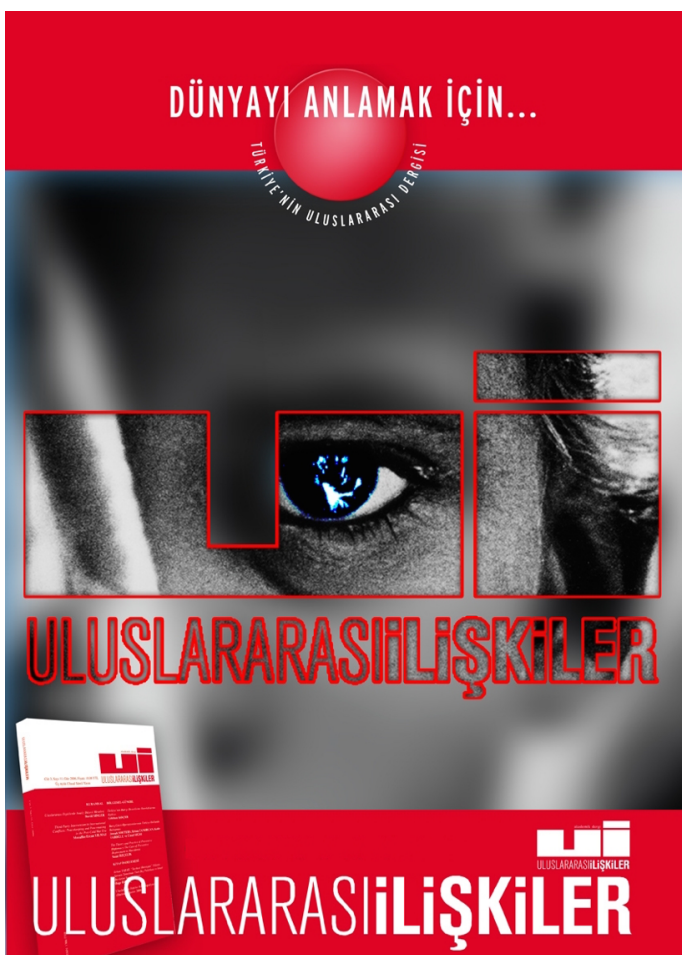

\title{
Yumuşak Güç Ölçülebilir mi?
}

\author{
Utku YAPICI* \\ * Yrd. Doç. Dr., Adnan Menderes Üniversitesi, Uluslararası \\ İlişskiler Bölümü
}

Bu makaleye atıf için: Yapıcı, Utku; "Yumuşak Güç Ölçülebilir mi?", Uluslararası İlişkiler, Cilt 12, Sayı 47, s. 5-25.

Bu makalenin tüm hakları Uluslararası İlişkiler Konseyi Derneği'ne aittir. Önceden yazılı izin alınmadan hiç bir iletişim, kopyalama ya da yayın sistemi kullanılarak yeniden yayımlanamaz, çoğaltılamaz, dağıtılamaz, satılamaz veya herhangi bir şekilde kamunun ücretli/ücretsiz kullanımına sunulamaz. Akademik ve haber amaçlı kısa alıntılar bu kuralın dışındadır.

Aksi belirtilmediği sürece Uluslararası Illişkiler'de yayınlanan yazılarda belirtilen fikirler yalnızca yazarına/yazarlarına aittir. UİK Derneğini, editörleri ve diğer yazarları bağlamaz.

Uluslararası İlişkiler Konseyi Derneği | Uluslararası İlişkiler Dergisi

Web: www.uidergisi.com.tr| E- Posta: bilgi@uidergisi.com.tr 


\title{
Yumuşak Güç Ölçülebilir mi?
}

\section{Utku YAPICI}

Yrd. Doç. Dr., Uluslararast İlişkiler Bölümü, Nazilli İİBF, Adnan Menderes Üniversitesi, Nazilli, Aydın. E-posta: yapiciutku@hotmail.com.

\section{ÖZET}

Bu makale son yıllarda akademik ve siyasal alanlarda adından söz ettiren bir güç kavramsallaştırması olan yumuşak güç üzerinedir. Makalede ilk olarak kavramın yaratıcısı Joseph S. Nye’ın görüşlerinden yola çıkılarak yumuşak gücün kuramsal temelleri hakkında bilgi verilecektir. Daha sonra yumuşak gücün ölçülebilirliği tartışması ile ilgili bir çözümlemeye girişilecek, ölçülebilirlik sorununa çözüm bulma denemeleri örneklendirilecektir. Bu kapsamda, yalnızca kamuoyu araştırmasına dayanan, yalnızca nicel verilere dayanan ve her ikisini bütünleme yolunu seçen denemelerin ölçülebilirlik sorununa çözüm bulmadaki başarı düzeyleri çözümlenecektir. Böylelikle yumuşak gücün bir “analiz kategorisi” olarak kullanılıp kullanılamayacağı sorusuna da cevap aranacaktır.

Anahtar Kelimeler: Yumuşak Güç, Ölçülebilirlik, Yumuşak Güç Endeksleri, Anketler.

\section{Can Soft Power be Measured?}

\begin{abstract}
This article is about a concept that has gained enormous academic and political popularity in the recent years: soft power. The study firstly focuses on the theoretical foundations of the soft power concept on the basis of Joseph S. Nye's views. After analyzing the measurement issues involved in assessing the presence of soft power, the study exemplifies discrete attempts to resolve the issue and evaluates those attempts' levels of success. In this way, the study tries to find an answer to the question on whether soft power should be used as a category of analysis or not.
\end{abstract}

Keywords: Soft Power, Measurability of Soft Power, Soft Power Indexes, Polls. 


\section{Giriş}

Uluslararası ilişkilerin değişen doğasında, devletlerin askeri-dışı araçlarla ve/veya zorlama-dışı tedbirlerle hedeflere ulaşma imkânı olduğu tezinin uzantısı olarak ortaya çıkan yumuşak güç kavramsallaştırması, üretildiği tarihten itibaren akademik ve siyasal alanlarda ilgi odağı olmuş, sıklıkla kullanılan, kullanıldığı bağlama göre de anlam değiştiren bir yapıya bürünmüştür. Bu kavramsallaştırma, kanıtlanabilir gerçekliğe sahip bir analiz kategorisi olduğu varsayımıyla kimi sosyal bilimciler tarafından kullanılırken ${ }^{1}$, eşzamanlı olarak gündelik sosyal ve siyasal yaşamda iddialara; bir pratik kategoriye dönüşmüştür. ${ }^{2}$ Yumuşak güç kavramsallaştırmasının siyasal söylevlerde bir başarı ölçütü olarak siyaset zeminine taşınması ve bir propaganda aracı olarak yaygın kullanımı, bu kavramsallaştırmanın bir pratik kategori haline dönüşümünün açık bir kanıtını oluşturmaktadır.

Böyle bir durumda analiz kategorisinin pratik kategori ile bitişikleşme riski doğmaktadır. $\mathrm{Bu}$ riski bertaraf etmek için kuramsal düzeyde yapılması gereken şey, yumuşak güç kavramına analitik bir içerik yükleyip onu analizin aracı olarak kullanmakta ısrarcı olmak olabilir. Nitekim sosyal bilimlerde kavramların eşzamanlı olarak analiz kategorisi ve pratik kategori olarak işlev görmeleri mümkün ve sık rastlanılan bir durumdur. ${ }^{3}$ Ancak kavramın bir analiz kategorisi haline getirilmesi kavramın gerçekliğinin kanıtlanmasını gerektirir. Varlığı kanıtlanamayan bir durum, bir başarı ölçütü olarak sunulamaz. Bu çalışmada yapılacak şey, aynı zamanda siyasal bir işleve de sahip olan yumuşak gücün ölçülebilirliğini sorgulamak; bu sorgulama üzerinden kavram ile ilgili ontolojik sonuçlara erişmektir.

Yumuşak güç ölçülebilirse bunun doğuracağı sonuçlar ne olacaktır? Peki ya ölçülemezse? $\mathrm{Bu}$ durumda yumuşak güç, bir terim olarak unutulmalı mıdır? Yumuşak gücün ölçülemezliği onun varlığının kanıtlanamaz olduğunu gösterir. Bir analiz kategorisi olarak değerlendirilmesini engeller. Yani yumuşak güç kavramsallaştırması analizin bir aracı olarak kullanılamaz. Ancak bu durum kavramın analiz dışı kaldığı anlamına gelmez. Kavramı analizin nesnesi haline getirmek mümkündür. ${ }^{4}$ Bir başka ifadeyle yumuşak güç kavramının bir pratik kategori, bir siyasal tabir ve iddia olarak nasıl çalıştığı, hangi meşrulaştırıcı işlevleri yerine getirdiği sorgulanarak kavram analiz nesnesi noktasına taşınabilir. Yumuşak güç ile ilgili siyasal söylevleri ve tartışmaları bu kavramın gerçekliğini varsaymadan çözümlemek mümkündür, aynı zamanda gereklidir. Ancak böyle bir sorgulama, elinizdeki çalışmanın sınırlarını aşmaktadır. Çalışma, yumuşak gücün ölçülebilirliği ve bu duruma bağlı olarak bir analiz kategorisi olarak kullanılıp kullanılmayacağı sorusu ile sınırlıdır. Bu soruya verilecek cevap, yumuşak gücü ya bir analitik araç biçiminde tutacak ya da son tahlilde araştırmanın yalnızca nesnesi haline taşıyacak çalışmalara kuramsal bir çıkış noktası sunacaktır.

1 Yumuşak gücün başlangıçtan bu yana politik bir doğaya sahip olduğu görüşü bu varsayıma bir itiraz oluşturur. Bkz. David Leheny, "A Narrow Place to Crooss Swords", Peter Katzenstein ve Takashi Shiraishi (der.), Beyond Japan, Ithaca, Cornell University Press, 2006, s.216-218'den aktaran Todd Hall, "An Unclear Attraction: a Critical Examination of Soft Power as an Analytical Category”, The Chinese Journal of International Politics, Cilt 3, Sayı 2, 2010, s.195.

2 Analiz kategorisi-pratik kategorisi ayrımı üzerine bkz. Adam Moore, "Rethinking Scale as a Geographical Category: from Analysis to Practice”, Progress in Human Geography, Cilt 32, Say1 2, s.206-208; Rogers Brubaker, Ethnicity Without Groups, Cambridge, Harvard University Press, 2004, s.31-33; Hall, "An Unclear Attraction”, s.189-211; Rogers Brubaker ve Frederick Cooper, “Beyond 'Identity”, Theory and Society, Cilt 29, Sayı 2, 2000, s.1-47.

3 "Interview with Rogers Brubaker (University of California: Los Angeles) Conducted by Franziska Meissner", Max Planck Gesellschaft, http://www.mmg.mpg.de/special-output/interviews/interview-with-rogers-brubaker-universityof-california-los-angeles/ (Erişim Tarihi 9 Nisan 2014).

4 Rogers Brubaker bu öneriyi millet kavramı için yapmıştır. Bkz. Rogers Brubaker, "In the Name of Nation: Reflections on Nationalism and Patriotism”, Citizenship Studies, Cilt 8, Sayı 2, Haziran 2004, s.116. 
Çalışmanın ilk bölümünde, yumuşak gücün kuramsal temelleri ve argümanları incelenecektir. Sonraki bölümde yumuşak gücün ölçülebilirliği sorununa bir çözüm olarak Nye’ın geliştirdiği metodolojik öneri tartışılacaktır. Daha sonra yumuşak gücün ölçümüne odaklanan denemeler aktarılacak, bu denemelerin başarı düzeyleri çözümlenecektir. Son olarak, yumuşak gücün ölçülebilirliği üzerine kuramsal bir değerlendirme yapılacaktır.

\section{Yumuşak Gücün Kuramsal Temelleri ve Argümanları}

Yumuşak güç kavramı 1990 yılında Nye’ın "Liderliğe Mecbur: Amerikan Gücünün Değişen Doğası" (Bound to Lead-The Changing Nature of American Power) isimli çalışmasıyla uluslararası ilişkiler literatürüne girmiş bir kavramdır. ${ }^{5}$ Ancak kavram oldukça yeni olsa da kavram aracılığıyla betimlenen olgunun uluslararası ilişkiler literatüründe tartışılması yeni değildir. Henüz iki dünya savaşı arasındaki dönemde Carr tarafından kaleme alınıp 1939 yılında ilk baskısını yapan "20 Yılın Krizi 1919-1939: Uluslararası İlişkiler Çalışmalarına Giriş” (The Twenty Years' Crisis 1919-1939: An Introduction to the Study of International Relations) başlıklı kitapta fikirler üzerindeki güçten bahsedilmiş, siyasal amaçlar için değerlendirildiğinde bunun askeri ve ekonomik güçten daha önemsiz olmadığı vurgulanmıştır. ${ }^{6}$ Melissen'in ifade ettiği gibi Carr'ın oldukça eski argümanını Nye'ın yakın tarihte ürettiği terminolojiye taşınması, sert güç (hard power) ile yumuşak gücün (soft power) ayrılmaz bir biçimde birbirlerine bağlı olduklarını ${ }^{7}$ ve yumuşak gücün dış politika açısından stratejik önemini ilk kavrayan uluslararası ilişkiler kuramcısının Carr olduğunu gösterir.

Carr'dan sonra da gerçekçi ekol içinde Nye’ın sonraki dönemlerde adlandıracağı yumuşak güç öğelerini güç unsurları arasında sayan kuramsal çalışmalara sıklıkla rastlanmıştır. Örneğin Morgenthau, 1948 yılında yayınladığı “Uluslararası Politika” adlı eserinde milli gücün unsurları arasında coğrafya, doğal kaynaklar, endüstriyel kapasite, askeri hazırlık derecesi ve nüfus gibi niceliksel öğelere ek olarak milli karakter, milli moral, diplomasinin niteliği gibi niteliksel öğelere de yer vermiştir. ${ }^{8}$ Gilpin, 1981 yılında ilk baskısını yapan "Dünya Politikasında Savaş ve Değişim” adlı eserinde devletin askeri, ekonomik ve teknik kabiliyetlerine ek olarak kamu morali, politik liderliğin meziyeti gibi gücün psikolojik ve kolay ölçülemez hallerinin de varlığını kabul etmiş, bu faktörleri nitelemek için "prestij" kavramından yararlanmıştır.9 Bu bağlamda yumuşak güç, gerçekçi ekolün düşünsel öncüllerinin yarattığı ancak Nye'ın da içinde yer aldığı neoliberal kurumsalcılık çerçevesinde ortaya atılan bir kavramsal yaklaşım olarak değerlendirilebilir. Bu süreklilik, gerçekçi ekol ile neoliberal kurumsalcılık arasında uluslararası ilişkilerin doğasına yönelik varsayım ortaklığının doğal bir sonucudur. ${ }^{10}$ Nitekim

5 Bkz. Joseph S. Nye Jr., Bound to Lead: The Changing Nature of American Power, New York, Basic Books, 1991, s. x-xii. Joseph S. Nye, Watanabe Yasushi ve David L. McConnell'in editörlüğünde çıkan "Yumuşak Güç Süpergüçleri” isimli kitaba yazdığı önsözde yumuşak güç kavramını 1989 yılında ürettiğini ifade etmektedir. Bkz. Watanabe Yasushi ve David L. McConnell (der.), Soft Power Superpowers - Cultural and National Assets of Japan and the United States, New York, M. E. Sharpe, 2008, s. ix.

6 E. H. Carr, The Twenty Years' Crisis 1919-1939: An Introduction to the Study of International Relations, Hong Kong, The MacMillan Press, 1981. Carr, fikirler üzerindeki gücü siyasal liderin ikna sanatı ve kitlesel propaganda bağlamlarda tanımlamıştır. Bkz. Carr, The Twenty Years' Crisis 1919-1939, s.132.

7 Bkz. Jan Melissen, “The New Public Diplomacy: between Theory and Practice”, Jan Melissen (der.), The New Public Diplomacy - Soft Power in International Relations, New York, Pallgrave McMillan, 2005, s.4.

8 Bkz. Hans J. Morgenthau, Politics among Nations - the Struggle for Power and Peace, New York, Alfred A. Knopf, 1949, s.96-108.

9 Robert Gilpin, War and Change in World Politics, Cambridge, Cambridge University Press, 1999, s.13-14.

10 Bkz. Robert Jervis, "Realism, Neoliberalism, and Cooperation: Understanding the Debate”, International Security, Cilt 24, Sayı 1, Yaz 1999, s.44, 47. 
neoliberal kurumsalcılık, Gerçekçilik ile uluslararası ortamın anarşik yapısı, devletlerin rasyonelüniter aktörlük statüsü gibi konularda aynı varsayımları paylaşmaktadır. Neoliberal kurumsalcılığın gerçekçilikten en belirgin farkı ise, uluslararası örgütler vurgusuyla anarşi ortamında bile uluslararası işbirliğinin mümkün ve aktör açısından rasyonel olduğu noktasındadır. ${ }^{11}$ Yumuşak güç, işbirliğinin mümkün ve rasyonel olduğu bir uluslararası sistemde devletlerin elini güçlendirmek için sahip olmaları gereken bir güç kategorisi olarak değerlendirilmiştir.

İstediğiniz sonuçları elde etme ve bu sonuçları elde etmek için gerekirse başkalarının davranışlarını değiştirme yeteneği olarak tanımlanan güç ${ }^{12}$, Nye’a göre de birçok kılığa bürünebilen bir olgudur. Yumuşak güç, tıpkı sert güç gibi söz konusu güç biçimlerinden biridir. Yumuşak güç kavramının genellikle yanlış anlaşıldığından, yanlış kullanıldığından ve önemsizleştirildiğinden yakınan $\mathrm{Nye}^{13}$, çalışmalarında bu güç biçiminin etkisiz güç anlamına gelmediğini vurgulama ihtiyacını duymuştur. Bir başka ifadeyle, bir aktörün bu tip bir güce sahip olması başlı başına zayıflık kaynağı oluşturmaz. ${ }^{14}$ Ancak dış politik zaferler için sadece yumuşak güç de yetmez. Dış politikada başarı, tıpkı Carr'ın İkinci Dünya Savaşı́nın hemen öncesindeki süreçte ifade ettiği gibi sert ve yumuşak güç arasında daha iyi bir denge kurmakla mümkündür -ki bu ideal durumu Nye "akıllı güç" (smart power) kavramıla açıklamaktadır. ${ }^{15}$ Akıllı güç ne sadece sert ne de sadece yumuşaktır; ikisidir. ${ }^{16}$

Nye yumuşak güç kavramını, sert güç kavramıyla karşılaştırarak tanımlamıştır. Askeri güç ve ekonomik kudret gibi sert güç araçları ile diğerlerinin pozisyon değiştirmelerini sağlamak sıklıkla mümkündür. Bu durum büyük ölçüde rüşvetlerle (havuç) veya tehditlerle (sopa) sağlanır. Oysa yumuşak güç, zorlama veya ödeme yapmaktan ziyade kendine çekme (cazip gelme) yoluyla istediğini yaptırabilme yeteneğidir. ${ }^{17}$ Diğer aktörlerinin güç sahibinin tercihlerine uygun olarak davranışlarını değiştirmeleri güç sahibinin onları bir maliyet-fayda hesaplaması yapmaya itmesi nedeniyle değil, güç sahibinin kimliğini ve politikalarını meşru görmeleri nedeniyle gerçekleşirse yumuşak güçten söz edilebilir. ${ }^{18}$ Eğer başkalarının peşinden gitmek istedikleri değerleri temsil ederseniz hedefleriniz daha ucuza mal olur. ${ }^{19} \mathrm{Bu}$ bağlamda yumuşak güç, istediğiniz şeyleri başkalarının istemesini sağlamanızla oluşur. ${ }^{20}$ Cezbetme çoğunlukla karşıdakini gönüllü itaatkârliğa veya taklide sevk eder. ${ }^{21} \mathrm{Bu}$ durum yumuşak güç sahibinin hedefe ulaştırmasını kolaylaştıran psikolojik süreçler yaratır.

Sert güç kaynakları ile yumuşak güç kaynakları arasındaki ayrım çok katı değildir. Sert güç kaynaklarının kimi durumlarda yumuşak güç kaynaklarına dönüşebilmesi sert-yumuşak güç ayrımını

11 Joseph M. Grieco, "Anarchy and the Limits of Cooperation: a Realist Critique of the Newest Liberal Institutionalism", International Organization, Cilt 42, Sayı 3, Yaz 1988, s.486, 494; Sheng Ding, "Analyzing Rising Power from the Perspective of Soft Power: a New Look at China's Rise to the Status Quo Power”, Journal of Contemporary China, Cilt 16, Say1 64, Mart 2010, s.259.

12 Joseph S. Nye Jr., Amerikan Gücünün Paradoksu, çev. Gürol Koca, İstanbul, Literatür Yayınları, 2003, s.5.

13 Joseph S. Nye Jr, Soft Power - the Means to Success in World Politics, New York, Public Affairs, 2004, s.xi.

14 Ibid. s.x.

15 Ibid. s. 147.

16 Ibid. s.xiii.

17 Ibid. s.5.

18 Tarık Oğuzlu, "Soft Power in Turkish Foreign Policy", Australian Journal of International Affairs, Cilt 61, Sayı 1, Mart 2007, s.83. Ayrıca bkz. Tarık Oğuzlu, "Soft Power: the Concept and Its Relevancy”, Bilgesam Analysis, Sayı 1125, 7 Nisan 2014, s.2; Kemal Kirişçi, “'Yumuşak Güç' Aracı Olarak Daha Dostça Bir Şengen Vize Sistemi: Türkiye’nin Deneyimi”, Uluslararası İlişkiler, Cilt 4, Sayı 13, Bahar 2007, s.27-56.

19 Bkz. Nye, Amerikan, s.11.

20 Nye bu durumu şöyle özetlemektedir: "Eğer istediğim şeyi istemeni sağlayabilirsem, o zaman yapmak istemediğin şeyi yapmaya seni zorlamama gerek kalmaz". Nye, Amerikan, s.11.

21 Ibid. s.11. 
karmaşıklaştırmaktadır. Örneğin bir devletin güçlü ekonomiye sahip olması sadece yaptırım veya dış yardımlar gibi sopa veya havuca olanak tanıyan sert güç kaynaklarına sahip olduğu anlamına gelmez. Güçlü ekonomiye sahip olma, hedef aktörlerin gözünde güç sahibinin çekiciliğini arttıran bir faktör olarak bir yumuşak güç kaynağına da dönüşebilir. ${ }^{22}$ Benzer bir biçimde devletlerin silahlı kuvvetleri, uygun zeminlerde kullanıldıklarında yumuşak gücü arttırıcı bir faktöre dönüşebilir. Naoyuki bu duruma örnek olarak Japonya Özsavunma Birlikleri'nin (Japan Self-Defense Force) Afganistan'da terörle mücadeleye yönelik Sürekli Özgürlük Harekâtı (Operation Enduring Freedom) ve Irak'ta Irak Özgürlük Harekâtı (Operation Iraqi Freedom) kapsamında konuşlanmasını göstermiştir. Naoyuki'ye göre Japonya birliklerinin söz konusu harekâtlarda görev yapması ABD düzleminde Japonya'nın yumuşak gücünü arttıran bir faktör olmuştur. ${ }^{23}$ Ancak aynı olgu, Japonya’nın bir başka devlet ile ilişkisinde yumuşak gücünü azaltan bir faktöre de dönüşebilir.

Bu demek oluyor ki, yumuşak ile sert güç kaynakları arasında - sonuçları itibariyle - genel geçer bir ayrım yapabilmek mümkün değildir. Benzer bir biçimde bir aktörün belirli bir süreçte bir diğer aktör ile ilişkisinde istenilen sonuçları elde etmek adına önemli etki yapan bir yumuşak güç kaynağı, bir başka süreçte aynı ya da bir başka aktör ile ilişkisinde etkisiz kalabilir ya da istenilen sonuçların tam tersi yönde etkiler doğurabilir. Dolayısıyla güç kaynakları, kullanıldıkları bağlamlara göre değerlendirilmelidir. Kimin yüksek karta sahip olduğunu söylemek için öncelikle ne oyun oynadığını, kartlarının değerlerinin ne şekilde değişebileceğini $i^{24}$ ve bu oyunun kiminle oynandığını bilmek gereklidir. Örneğin, Nye’ın ifade ettiği gibi Amerikan kültürünün dünya geneline ulaşması $A B D$ yumuşak gücünün artmasına yardımcı olabilir. Bireycilik ve özgürlükler çoğu insana cazip gelir ancak bazılarına "iğrenç" de gelebilir. ${ }^{25}$ Mingjiang Li'nin ifade ettiği gibi ABD liberal demokrasisi bir ideoloji olarak dünya çapında sosyo-politik elitlerin birçoğuna çekici gelebilir. Ancak demokrasiyi iç siyasal güçlerine tehdit sayan yöneten elitler için değerlendirildiğinde söz konusu ideolojik aygıtın bir yumuşak güç kaynağı oluşturmadığı görülür. Ya da Çin Halk Cumhuriyeti’nin siyasal otoriterliğe eklediği ekonomik liberalizm birçok üçüncü dünya ülkesi nezdinde Çin’in yumuşak gücünü arttırırken, aynı faktör Batılı güçler ile ilişkiler düşünüldügünde Çin’in yumuşak gücünü zayıflatır. ${ }^{26}$

Yumuşak güç araçlarına sahip olmak otomatik olarak yumuşak güce sahip olmak anlamına gelmez ${ }^{27}$ - ki aynı durum "sert güç" açısından da geçerlidir. ${ }^{28}$ İster yumuşak isterse sert olsun, bir gücün varlığından söz edebilmek için üç temel koşul aranır: Devletlerin diğer aktörleri yönlendirme konusunda imkânlara/varlıklara sahip olmaları, bu güç varlıklarını elinde tutan aktörlerin söz konusu güce sahip olma bilinçleri ve sistemdeki diğer aktörlerin bu gücün farkına varmaları. Bir başka ifadeyle güç davranışsal bir biçimde tanımlanır, etkileşimsel bir biçimde kurulur. Bir gücün varlığından söz edebilmek için ise diğer aktörlerin güç sahibi tarafın çıkarlarına uygun bir biçimde politikalarında

22 Ancak sert güç kaynaklarına sahip olma ile yumuşak güce erişim arasındaki bağlantı her zaman yukarıdaki gibi değildir. Örneğin Nye'ın belirttiği gibi yakın geçmişte Norveç, büyük ekonomik ve askeri kaynaklara sahip olmamasına rağmen barış görüşmeleri konusundaki inisiyatifi ile yumuşak güç elde etmiştir. Bkz. Nye, Soft Power, s. 9-10.

23 Ayrıntılı bilgi için bkz. Agawa Naoyuki, "Japon Does Soft Power - Strategy and Effectiveness of its Public Diplomacy in the United States”, Watanabe Yasushi ve David L. McConnell (der.), Soft Power Superpowers - Cultural and National Assets of Japan and the United States, New York, M.E. Sharpe, 2008, s.236-237.

24 Nye, Soft Power, s.6-7.

25 Nye, Amerikan, s.ix.

26 Bkz. Yasushi ve McConnell (der.), Soft Power, s.x. Ayrıca bkz. Mingjiang Li, “Soft Power: Nurture or Nature”, Mingjiang Li (der.), Soft Power - China's Emerging Strategy in International Politics, Plymouth, Lexington Books, 2009, s.6.

27 Yumuşak güç kaynağı olarak görülen kültür, ideoloji, değer ve normların sık sık kırgınlık, nefret, düşmanlık ve hatta çatışmalara vesile oldukları eleştirisi için bkz. Li, Soft Power, s.4.

28 Tarık Oğuzlu, “On Power”, SEPAM Policy Brief, Sayı 5, Temmuz 2014, s.4. 
değişim gerçekleştirmeleri de şarttır. ${ }^{29}$ Bu değişimin saptanmasıyla yumuşak gücün ölçülebilir bir hale geldiği söylenir. Ancak hedef aktörün politikalarındaki istenilen bir değişimi saptamak, bir aktörün yumuşak güç sahibi olduğunu saptamak için gereklidir, fakat yeterli değildir. Güç sahibi devletin hedefleri ile bu değişim arasında bir nedensellik bağının da bulunması gerekir. Bir başka ifadeyle, ülkenin kültürü, siyasal idealleri ve politikalarından kaynaklanan bir çekiciliği oluşur, bir aktörün politikaları diğerleri tarafından meşru bir biçimde algılanır ve bu algının etkisiyle hedef aktörün eylemlerinde istenilen bir değişim sağlanırsa o aktörün yumuşak gücünün varlığı kabul edilir. ${ }^{30}$

\section{Yumuşak Gücün Kaynakları Konusunda Nye'ın Sınıflandırması}

Nye’a göre üç potansiyel yumuşak güç kaynağından söz edebilmek mümkündür. Bu kaynaklardan ilki kültürdür. Edebiyat, sanat, eğitim gibi alanlar hedef aktörün elitlerinin etkilenmesinde daha fazla önem taşırken kitlesel eğlence üzerine odaklanan popüler kültür geniş halk kesimlerinin yönlendirilmesinde önemli kabul edilebilir. ${ }^{31}$ İkinci potansiyel yumuşak güç kaynağı politik değerler, üçüncüsü $d$ `ş politikalardır. Üç potansiyel güç kaynağı hedef tarafından çekici görüldügünde, meşru kabul edildiğinde ve moral otoriteye sahip olduğunda gerçek bir yumuşak güç kaynağına dönüşebilir. ${ }^{32}$

Bu noktada Nye'ın potansiyel yumuşak güç kaynaklarından biri olarak değerlendirdiği kültür konusunda bir parantez açmakta yarar vardır. Nye'ın yumuşak güç kavramsallaştırması devlet ile kültür arasında bir uyumun varlığını bir veri olarak kabul etmektedir. Kuramın esas sorunlu yanını da bu ön kabul oluşturmaktadır. Oysa devlet-kültür özdeşliğini çağrıştıracak bir yaklaşım sorunludur. Dahası ülke ve kültür arasındaki keşişim kümesinin büyüklüğü zaman ve mekâna göre değişebilmektedir. Küreselleşmenin etkisi ile birlikte bir ülkenin sınırları ötesine yayılan sosyal ilişki biçimleri "kültürün yurtsuzlaşması" (deterritorialization of culture) olgusunu daha fazla gündeme getirmiştir. Bir toplum içinde farklı kültürel çatıların varlığı durumu daha da karmaşıklaştırmaktadır. Benzer biçimde devletin bütünleşik bir kamu çıkarını yansıttığı tezi de tartışmaya açıktır. ${ }^{33}$ Tüm bunlar, Nye’ın kültür-devlet ilişkisi düzleminde fazla basitleştirilmiş yaklaşımını yeniden değerlendirmeye ihtiyaç olduğunu göstermektedir.

Ayrıca yukarıda sayılan yumuşak güç kaynaklarının bütünüyle devletlerin kontrolünde olmaması da üzerinde dikkatle durulması gereken bir diğer husustur. Nye'ın ifade ettiği gibi firmalar, üniversiteler, vakıflar, kiliseler, diğer hükümet dışı gruplar gibi yumuşak gücün özel kaynakları kendi yumuşak güçlerini kendileri üretirler. Bu durum resmi dış politika hedeflerini besleyebileceği gibi kimi durumlarda resmi dış politika hedefleriyle çelişebilir de. Bir ülkenin potansiyel yumuşak güç kaynağı olarak değerlendirilebilecek kurumların bu durumda devlet yönetiminin yumuşak gücünü azaltıcı bir faktöre dönüşmesi de olasılık dâhilindedir. ${ }^{34}$ Dolayısıyla potansiyel yumuşak güç kaynaklarının stratejileri daha ciddi bir biçimde değerlendirmeye tabi tutulmalıdır.

29 Oğuzlu, "Soft Power", s.82, 83.

30 Nye, Soft Power, s.x.

31 Nye, Soft Power, s.11.

32 Ibid. s.11-13. Ayrica bkz. Joseph S. Nye Jr., "Public Diplomacy and Soft Power", The Annals of the American Academy of Political and Social Science, Cilt 616, Sayı 1, Mart 2008, s.96-99.

33 Bu konuda bir tartışma için bkz. Utku Yapıcı, Sovyet Sonrası Coğrafyada Devlet ve Milliyetçilik, Ankara, Tan Yayınları, 2011, s.57-59; Bkz. Yasushi ve McConnell (der.), Soft Power, s.xxi.

34 Nye, Soft Power, s.17. Nye, bu tezine bir kanıt olarak, Vietnam Savaşı sırasında ABD'de popüler firmaların veya sivil grupların, resmi dış politika hedefiyle zaman zaman çatışan kendi yumuşak güçlerini oluşturduklarını aktarmaktadır. Bkz. Nye, Amerikan, s.14. 
Nye'ın son yıllarda devletin kendini eleştirme konusundaki istekliliğini de yumuşak güç bağlamında değerlendirdiği gözlenmektedir. Nye bu durumu "meta-yumuşak güç" kavramıla açıklamaktadır. Devletin eleştiriye açık oluşu Nye’a göre devletin başkaları gözünde çekiciliğini, meşruiyetini ve güvenilirliğini arttırır. Dolayısıyla içeride baskı ve yıldırma politikaları ile eleştirilemez kılınan bir hükümet, kutsallaştırılan bir lider ya da tektipleştirici bir ideoloji, dışarıda devletin yumuşak gücünün azalması riski yaratır. ${ }^{35}$ Ancak "meta-yumuşak güç" tartışılırken de bağlamın mutlaka değerlendirilmesi gerekliliği dikkate alınmalıdır. Kimi durumlarda kimi hedef aktörler için eleştirilmez bir hükümet, kutsallaştırılan bir lider ya da tektipleştirici bir ideoloji demokratik çoğulculuktan daha çekici gelebilir. Genel geçerlikten uzak durma zorunluluğu, Nye'ın da kabul ettiği gibi, yumuşak gücün etkileşimsel bir biçimde inşa edilmesinin doğal bir sonucudur.

\section{Yumuşak Gücün Ölçülebilirliği Tartışmasında Nye'ın Konumu}

Bir aktörün sahip olduğu yumuşak gücün o aktörün dış politika başarısı olarak yorumlanması konusunda gerek politika sahnesinde gerekse uluslararası ilişkiler literatüründe bir oydaşım olduğu doğrudur. Ancak yumuşak güce sahip olmayı bir “başarı öyküsü” olarak tanımlamadaki oydaşım, neyin başarı olduğu hakkında nesnel kriterler saptama konusunda fikir birliğini beraberinde getirmemiştir. Oysa Johnson'un ifade ettiği gibi gerçekten başarılı olmak başarıyı tanımlayabilmekten geçmektedir. ${ }^{36}$ Nesnel başarı ölçütlerinin tanımlanması konusundaki sıkıntılar ise yumuşak gücün ölçülebilirliğinin ve son tahlilde varlığının sorgulanması sonucunu doğurmaktadır. "Ölçülemeyen şey gerçekten var mıdır?” sorusu bu bağlamda, tartışmanın temel sorusu olmaktadır.

Tartışmaya, kavramın yaratıcısı Nye’ın ölçülebilirlik konusundaki sıkıntının farkında olduğu söylenerek başlanabilir. Nye, ölçülebilirlik sorununu yöntemsel müdahalelerle aşılabilecek bir sorun olarak değerlendirmiş, iki aşamalı bir izlek önermiştir. Birinci aşama, bir varlığın yumuşak güç kaynağı olup olmadığının saptanması, ikinci aşama ise bir varlığın yumuşak güç kaynağı olmasıyla açığa çıkan cazibenin, arzulanan dış politik sonuçları üretip üretmediğinin belirlenmesidir. Nye, bir varlığın cazibeyi sağlayan yumuşak güç kaynağı olup olmadığının hedef kitleye anket uygulanarak ölçülebilir olduğunu iddia etmektedir. Bu cazibenin, karşılığında istenilen politik sonuçlar üretip üretmediğinin ise özel vakalarda ayrı ayrı değerlendirilmesi gerektiğini ifade etmektedir. ${ }^{37}$

Nye’ın ölçülebilirlik konusundaki iyimserliği, ürettiği izleğin iki aşamasıyla ilgili çekinceleri ortaya koymasıyla zayıflamaktadır. Nitekim Nye’a göre yumuşak güç kaynaklarının ölçümünde anket uygulaması asli fakat eksik bir yöntemdir. Bu eksikliğin iki nedeni vardır. Birincisi, cevapların, soruların formülleşme biçimlerine bağımlı olarak değişebilirliğidir. İkincisi, anketlerin sürekliliği değil anı temsil etmeleridir. ${ }^{38} \mathrm{Bu}$ noktada Nye'ın birinci eksiklik nedenine uygun bir çözüm önermeden ikinci eksiklik nedenine yoğunlaştığı dikkat çekmektedir. Nye’ın ikinci eksiklik nedeni ile ilgili çözüm önerisi ise hedef kitle üzerinde oluşan etki seviyesini bir süreklilik çerçevesinde çözümleyebilmek için aynı anketin hedef kitle üzerinde belirlenmiş zaman aralıklarıyla tekrarlanmasıdır. ${ }^{39}$ Sonuç olarak anketlerin yönlendiriciliği ve bu bağlamda sonuçlar üzerindeki biçimlendirici-sınırlandırıcı etkisi Nye tarafından kabul edilmektedir. Ancak Nye, bu kritik sorunun çözümü noktasında bir yöntem önerisi

35 Yasushi ve McConnell (der.), Soft Power, s.xxiii.

36 Joe Johnson, “How Does Public Diplomacy Measure Up?”, Foreign Service Journal, Ekim 2006, s.44.

37 Nye, Soft Power, s.6.

38 Ibid. s.18.

39 Ibid. s.18. 
getir(e)memekte, anketlerin etki değerlendirme fonksiyonunun sadece anlık olmasına ise anket tekrarlama yöntemiyle çözüm aramaktadır.

Bir varlığın yumuşak güç kaynağı olmasıyla ortaya çıkan cazibenin arzulanan dış politik sonuçları üretip üretmediğinin belirlenmesi konusundaki sınıllılılar da Nye tarafından kabul edilmektedir. Nye, cazibenin her zaman tercihleri belirlemediği, ancak kaynak olarak ölçülen güç ile davranışsal çıktılar olarak yorumlanan güç arasındaki boşluğun yumuşak güce özgü olmadığını, her güç biçimleri tarafından paylaşıldığı fikrini savunmaktadır. Nye bu konuda bir sert güç unsuru olan askeri kapasite ile ilgili bir örnek vermektedir. İkinci Dünya Savaşı sırasında 1940 yılında Fransa teslim olmadan önce İngiltere ve Fransa'nın Almanya'dan daha fazla tanka sahip olduğunun vurgulanmakta olduğunu ancak askeri güç kaynaklarındaki bu avantajın savaşın sonucunu doğru olarak öngörmediğini ifade etmektedir..$^{40}$ Nye'ın söz konusu yargısı, yumuşak gücün ontolojik olarak sert güçten farklı bir güç kategorisi olmadığını tezini savunmak anlamına gelmektedir. Ancak sert gücün ölçülebilirliği konusundaki bir sıkıntı merkeze alınarak bu vurgu yapılmıştır ki, söz konusu vurgu son tahlilde yumuşak gücün ölçülebilirliğinin okuyucu tarafından daha fazla sorgulanmasından başka bir sonuç doğurmamaktadır.

\section{Ölçülebilirlik Sorununa Çözüm Arayışları: Nye'in Sınıflandırmasını Derinleştirme Girişimleri, Anketler ve Yumuşak Güç Endeksleri}

Yumuşak güç konusunun son yıllarda akademi ve politika düzlemlerinde artan oranda ilgi uyandırmasına rağmen, gücün ölçülmesi konusundaki literatür büyük oranda ekonomik ve askeri kapasiteye odaklanmayı sürdürmektedir. ${ }^{41}$ Literatürde sert güç kaynaklarının ölçümüne odaklanma, genellikle ekonomik ve askeri kapasitelerin, kültür ve diplomasi gibi yumuşak güç unsurlarına kıyasla daha somut, ölçülebilir ve karşılaştırılabilir veri setleri olarak yorumlanmasından kaynaklanmaktadır. Buna rağmen, son yıllarda yumuşak gücün ölçülebilirliğini kabul eden araştırmacılar tarafından, bu güç biçiminin alt kategorilerini betimlemeye ve alt kategorilerin etki ağırlıklarını sınıflandırmaya yönelik endeksleme girişimlerine sınırlı da olsa rastlanmaktadır. ${ }^{42}$ Kimi örneklerde ise endekslerin

40 Ibid. s. 18.

41 Örnekler için bkz. Jean François Simard ve Pierre C. Pahlavi, "Measuring the Effects of Soft Power, Vanguard Magazine, Mayıs/Haziran 2009, http://vanguardcanada.com/measuring-the-effects-of-soft-power/ (Erişim Tarihi 25 Ocak 2014). J. David Singer et.al., "Capability, Distribution, Uncertainty and Major Power War, 1980-1965, Bruce Russett (der.), Peace, War, and Numbers, Beverly Hills, Sage, 1972, s.19-48. Stephen L. Jen ve Fatih Y1lmaz, "Hard Power of Nations”, 13 Kasım 2012, http://sljmacro.com/wp-content/uploads/2012/01/Hard-Power-of-Nations.pdf (Erişim Tarihi 25 Ocak 2014). "Countries Ranked by Military Strength (2013)”, GFP, http://www.globalfirepower.com/ countries-listing.asp (Erişim Tarihi 25 Ocak 2014). James Ball, “Infographic: Who is Leading the Arms Race?”, The Guardian, 16 Haziran 2013, http://www. theguardian.com/uk/datablog /picture/2013/jun/16/infographic-wholeading-the-arms-race (Erişim Tarihi 25 Ocak 2014). Gregory F. Treverton ve Seth G. Jones, Measuring National Power, Santa Monica, Rand Corporation, 2005, s.3.

42 Yumuşak güç kavramsallaştırması ile ilgili yayınların ezici bir çoğunluğunda, yayının konusunu oluşturan aktörün yumuşak gücünün artması ya da azalması üzerine bir tez ileri sürülmekte, yumuşak gücün kaynakları sınıflandırılmakta ve kaynaklar konusunda kronolojik gelişmeler sayılarak çalışma tamamlanmakta, gücün ölçülmesi ile ilgili denemelere hiç girişilmemektedir. Örnekler için bkz. Yiwei Wang, "Public Diplomacy and the Rise of Chinese Soft Power", Annals of the American Academy of Political and Social Science, Cilt 616, Mart 2008, s.257-273; Bates Gill ve Yanzhong Huang, "Sources and Limits of Chinese 'Soft Power”, Survival: Global Politics and Strategy, Cilt 48, Say1 2, Yaz 2006, s.17-36; Peng Er Lam, “Japan's Quest for 'Soft Power': Attraction and Limitation”, East Asia, Cilt 24, Say1 4, Aralık 2007, s.349-363; Nissim Kadosh Otmazgin, Contesting Soft Power: Japonese Popular Culture in East and Southeast Asia”, International Relations of the Asia-Pacific, Cilt 8, Say1 1, 2008, s. 73-101. Zülfikâr Bayraktar, “Türkiye'nin Balkanlar'daki Yumuşak Gücü Türk Kültürü”, Karadeniz Araştırmaları, Sayı 35, Güz 2012, s.181-189. 
kullanıldığı kamuoyu araştırması çalışmaları ile istatistiksel verilere ulaşılmaktadır. ${ }^{43}$ Ancak bu çalışmaların tümü metodolojik olarak ekonomik ve askeri kapasite konusunda daha önceden yapılmış anket ve endeksleme çalışmalarını takip etmekle yetinmektedir. İlgilendikleri aktörlerin yumuşak güç kapasitelerini ölçmeye odaklanmakta, kamuoyu algısına yönelik araştırmalar yapmakta, ancak kapasitenin kullanımı ile hedef aktördeki dış politika değişimi arasındaki bağlantıyı ortaya koymak gibi yumuşak gücün varlığını kanıtlayabilmek için zorunlu bir adımı genellikle es geçmektedir.

Literatürde Nye'in yumuşak gücün kaynakları konusundaki üçlü ayrımını (kültür, politik değerler ve dış politikalar) derinleştirerek yumuşak gücün kaynaklarını sınıflandıran birçok yayın mevcuttur. Örneğin McClory, kültür, yönetim, diplomasi, eğitim ve iktisadi faaliyet/buluşu temel yumuşak güç kategorileri olarak sunmuştur. ${ }^{44}$ Zheng şu ölçütlere göre Çin'in yumuşak gücünü tartışmaya açmıştır: Yatırım, barışı koruma ve insani yardım faaliyetleri, değişim programları, diplomasi kabiliyeti ve uluslararası örgütlere aktif katılım. ${ }^{45}$ Yasushi ve McConnell tarafından derlenen "Yumuşak Güç Süpergüçleri” başlıklı çalışmada ise ABD ve Japonya’nın yumuşak güçleri yüksek eğitim, popüler kültür, kamu diplomasisi ve sivil toplum bağlamlarında çözümlenmiştir. ${ }^{46}$ Söz konusu derinleştirme girişimleri aşağıda örneklenen çeşitli anket ve endeksleme çalışmalarına da rehberlik etmiştir.

\section{Yalnızca Kamuoyu Araştırmalarına Dayanan Denemeler}

Yalnızca kamuoyu araştırmalara dayanan denemelere en kapsamlı örneklerden biri Pew anketleridir. Washington merkezli "siyaset dişı bir bilgi kuruluşu” olan Pew Araştırma Merkezi (Pew Research Center) tarafından 2001 yılından bugüne, dünya çapında kamuoyu anketleri düzenlenmektedir. ${ }^{47}$ Söz konusu anketler, ilgilendiği farklı konuların yanında devletlerin yumuşak gücünün ölçümü üzerine de küresel düzeyde önemli çalışmalar arasında değerlendirilmektedir. Bu çalışmalar, yumuşak gücün ölçümü konusundaki genel eğilime uyarak devletlerin yumuşak güçleri ile ilgili saptamalarını tamamen anket sonuçlarına dayandırmaktadır. ${ }^{48}$ Anketler ise bilgisayar destekli telefon görüşmeleri ve yüz yüze görüşme yöntemleri ile gerçekleştirilmektedir. ${ }^{49}$

Ankette kimi sorular araştırma evrenini oluşturan tüm ülkelerden seçilen örneklemlere sorulurken, kimileri ise bir ya da birkaç ülkeden seçilen örneklemlere sorulmuştur. ${ }^{50}$ Soruların

43 Simard ve Pahlavi, "Measuring the Effects".

44 Jonathan McClory, “The New Persuaders: an International Ranking of Soft Power”, Institute for Government, 2010, http:// www.instituteforgovernment.org.uk/sites/default/files/publications/The\%20new\%20persuaders_0.pdf (Erişim Tarihi 26 Kasım 2013).

45 Denise E. Zheng, “China's Use of Soft Power in the Developing World”, Carola McGiffert (der.), Chinese Soft Power and Its Implications for the United States, Washington, CSIS, 2009, s.1-9.

46 Bkz. Watanabe Yasushi ve David L. McConnell (der.), Soft Power Superpowers-Cultural and National Assets of Japan and the United States, New York, M.E. Sharpe, 2008. Konu Türkçe literatürde de tartışılmaktadır. Örneğin Emel G. Oktay’a göre bir ülkenin yumuşak gücüne katkıda bulunan unsurlar, kullanılan dil, yazarlar, yayıncılar, medya grupları, gazeteciler, sivil toplumun varlığı ve başarıları, siyasi partiler ve politikacılar, özel sektör, üniversiteler, akademisyenler, sanatçılar, sanatsal aktiviteler, müzik kanalları, hit olan parçalar, spor müsabakaları, ve sporculardır. Bu kapsamda, resmi düzeyde hükümetler tarafından düzenlenen konferanslar, seminerler, öğrenci değişim programları, burslar, yardım programları önemli yumuşak güç unsurları olarak değerlendirilmektedir. Emel G. Oktay, "NATO’nun Dönüşümü ve Kamu Diplomasisi'nin Artan Rolü”, Uluslararası İlişkiler, Cilt 9, Sayı 34, Yaz 2012, s.131-132.

47 "About the Paw Research Center”, Pew Research Center, http://www.pewresearch.org/about/ (Erişim Tarihi 27 Ocak 2014).

48 “The New Persuaders III", Institute for Government, http://www.instituteforgovernment.org.uk/sites/ default/files/ publications/The\%20new\%20persuaders\%20III_0.pdf (Erişim Tarihi 27 Ocak 2014).

49 Bkz. "Datasets", Pew Research Center, http://www.pewglobal.org/category/datasets/ (Erişim Tarihi 28 Ocak 2014).

50 Bkz. "Pew Research Center Global Attitudes Project Spring 2012 Questionnaire", Pew Research Center, http://www. pewglobal.org/category/datasets/?download=27361 (Erişim Tarihi 28 Ocak 2014). 
hepsinin devletlerin yumuşak güçlerini ölçmek ile ilgili olmaması, anketin yumuşak güç bağlamında bir elekten geçirilerek yorumlanmasını gerektirmektedir. Örneğin 2012 yılı anketinde tüm ülkelerden örneklemlere Barack Obama'nın yeniden seçilip seçilemeyeceği konusunda öngörüleri sorulmuştur (Soru 10) ki bu öngörü sorusuna verilecek yanttlar ABD’nin yumuşak gücü konusunda net bir fikir vermemektedir. Oysa örneğin ülkelerden seçilen örneklemlerin diğer ülkeler hakkındaki genel fikirleri (Soru 8), dünyanın en büyük ekonomik gücünün hangi ülke olduğu (Soru 29) ve kimi liderlere duyulan güveni ölçen sorular (Soru 40, 44) yumuşak güç konusunda bir anlam taşımaktadır. ${ }^{51} \mathrm{Bu}$ demek oluyor ki, Pew anketleri devletlerin yumuşak güçleri konusunda hedef kamuoyundaki algıyı oldukça dağınık konu başlıklarındaki anket sorularına verilen cevaplarla ölçmeye çalışmış, tutarlı bir endeksleme yöntemi geliştirememiştir.

\section{Yalnızca Nicel Verilere Dayanan Denemeler}

Yalnızca nicel verilere dayanan denemelere en kapsamlı örnek Hızlı Büyüyen Pazarlar Yumuşak Güç Endeksi'dir (Rapid Growing Markets Soft Power Index). ${ }^{52}$ Söz konusu girişim, Ernestł'Young's Emerging Markets Center tarafından 2005 yılından günümüze kadar her yll tekrarlanan bir endeksleme çalışmasıdır. Endeksin en önemli ayırt edici özelliği kamuoyu araştırmalarına değil, nesnel nicel verilere dayanma iddiasındaki bir çalışma olmasıdır. Bu bağlamda her biri hakkında nicel verilere ulaşılacağı varsayılan 13 adet yumuşak güç değişkeni belirlenmiş, bu değişkenler kullanılarak devletlerin yumuşak güçleri karşılaştırmalı bir biçimde çözümlenmeye çalışılmıştır. Söz konusu 13 değişken üç temel alt endeks içinde yer almıştır: Küresel erdem, küresel kaynaşma ve küresel imaj. Küresel erdem alt endeksi içinde ülkenin etik ve moral düsturlara bağlılığını ölçmek hedeflenmektedir. Hukukun üstünlüğü, özgürlük, seçim katılım oranı ve karbon dioksit salınımı oranları bu bağlamda veri setlerinin başlıklarını oluşturmaktadır. Küresel kaynaşma alt endeksi içinde dünyanın geri kalanıyla ülkenin kurmuş olduğu ilişkinin biçimi ve boyutu saptanmaya çalışılmaktadır. Ülkede yaşayan göçmen sayısı, ülkeye gelen turist sayısı, ülke üniversitelerinin dünyanın en iyi üniversiteleri sıralamasındaki yeri, ülkedeki İngilizce bilme düzeyi verileri yumuşak gücün diğer kriterleri olarak sunulmaktadır. Küresel imaj alt endeksinde ise ülkenin küresel popülaritesini ve sahip olduğu hayranlık düzeyini saptamaya çalışan veri setleri oluşturulmaktadır. Bu çerçevede ülke kaynaklı medya ürünlerinin ihraç rakamları, ülke dilinin popülerliği, kazanılan olimpik madalyalar, küresel ikon olan yurttaş sayısı, beğenilen ülke kaynaklı şirket sayısı faktörleri değerlendirilmektedir. ${ }^{53}$

Tablo 1'de görüldüğü gibi, yukarıda aktarılan 13 değişkenden her biri için, değişkene ilişkin değerin, ilgili değişken grubunun toplam değerindeki payını ifade eden bir ağırlık katsayısı saptanmışır. $\mathrm{Bu}$ yolla, araştırma evrenini oluşturan her devletin bir yumuşak güç puanı belirlenmiş, devletlerin yumuşak güçlerini ölçme ve sıralama iddiasındaki endeksleme çalışması tamamlanmıştır. ${ }^{54}$ Veri kaynakları olarak ise çeşitli hükümetlerarası/ulus üstü örgüt, hükümet dışı uluslararası örgüt, meslek örgütü, sivil toplum örgütü, dergi, ulusal düzeyde resmi veri, ansiklopedi ve internet kaynaklarının kullanımı dikkat çekmektedir.

51 Ibid.

52 Bu kapsamdaki bir başka endeksleme girişimi için bkz. Tingshan Song ve Shanshan Chen, "Construction and Measure of the Evaluation Index System of Regional Soft Power-Taking Shandong Province as an Example, Studies in Sociology of Science, Cilt 3, Say1 4, 2012, s.85-91.

53 Bkz. "Rapid Growing Markets Soft Power Index Spring 2012”, ErnstおYYoung, http://emergingmarkets.ey. com/wpcontent/uploads/downloads/2012/05/TBF-606-Emerging-markets-soft-power-index-2012_LR.pdf (Erişim Tarihi 4 Şubat 2014), s.4-22.

54 Ibid. s.18-19. 
Tablo 1: 2012 Yılı Hızlı Büyüyen Pazarlar Yumuşak Güç Endeksi’nde Değişkenler, Ağırlıklar ve Veri Kaynakları

\begin{tabular}{|c|c|c|c|}
\hline $\begin{array}{l}\text { Alt } \\
\text { Endeks }\end{array}$ & Değişken & Ağırlık & Veri Kaynağı \\
\hline \multirow{4}{*}{ 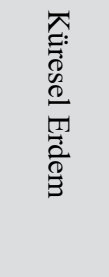 } & Hukukun Üstünlüğü & 11 & Dünya Bankası Yönetişim Göstergeleri \\
\hline & Özgürlük & 7.5 & Freedom House Endeksi \\
\hline & Seçimlere Katılım Oranı & 7.5 & Demokrasi ve Seçim Yardımı Enstitüsü \\
\hline & Karbon Dioksit Salınımı Oranı & 3.75 & Birleşmiş Milletler İstatistikleri \\
\hline \multirow{4}{*}{ 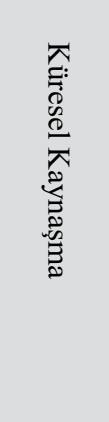 } & Ülkede Yaşayan Göçmen Sayısı & 11 & Birleşmiş Milletler Nüfus Birimi \\
\hline & Ülkeye Gelen Turist Sayısı & 11 & Dünya Turizm Örgütü \\
\hline & $\begin{array}{l}\text { Ülke Üniversitelerinin } \\
\text { Dünyanın En İyi Üniversiteleri } \\
\text { Sıralamasındaki Yeri }\end{array}$ & 11 & Times Higher Education Verileri \\
\hline & $\begin{array}{l}\text { Ülkedeki İngilizce Bilme } \\
\text { Düzeyi }\end{array}$ & 7.5 & $\begin{array}{l}\text { Ulusal Sayım Raporları, Anketler, Cambridge } \\
\text { Encyclopedia of the English Language, Wikipedia } \\
\text { Tarafından Çeşitli Kaynaklardan Derlenen Veri }\end{array}$ \\
\hline \multirow{5}{*}{ 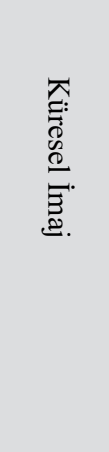 } & $\begin{array}{l}\text { Ülke Kaynaklı Medya } \\
\text { Ürünlerinin İhraç Rakamları }\end{array}$ & 3.75 & UNACTD \\
\hline & Ülke Dilinin Popülerliği & 3.75 & $\begin{array}{l}\text { Modern Language Asssociation (MLA) Dil Veritabanı } \\
\text { ve Eurostat }\end{array}$ \\
\hline & Kazanılan Olimpik Madalyalar & 3.75 & Uluslararası Olimpiyat Komitesi \\
\hline & $\begin{array}{l}\text { Küresel İkon Olan Yurttaş } \\
\text { Sayısı }\end{array}$ & 7.5 & Time 100 En Etkili Kişi \\
\hline & $\begin{array}{l}\text { Beğenilen Ülke Kaynaklı Şirket } \\
\text { Sayısı }\end{array}$ & 11 & Fortune Dergisi \\
\hline
\end{tabular}

Kaynak: "Rapid Growing Markets Soft Power Index Spring 2012”, Ernst and Young Resmi Internet Sitesi, http:// emergingmarkets.ey.com/wp-content/uploads/downloads/2012/05/TBF-606-Emerging-markets-soft-po werindex-2012_LR.pdf (Erişim Tarihi 4 Şubat 2014), s.18'den derlenmiştir.

\section{Kamuoyu Araştırmaları ile Nicel Verileri Bütünleyen Denemeler}

Yumuşak gücün kaynakları konusunda yukarıda aktarılan derinleştirme çabalarından beslenen endeksleme girişimlerinden bazıları kamuoyu araştırmaları ile nicel verileri bütünleme yöntemini uygulamıştır. İngiltere'nin önde gelen düşünce kuruluşlarından Institute for Government ile bir life-style dergisi olan Monocle tarafindan 2010, 2011 ve 2012 yillarında hazırlanan The New Persuaders (Yeni İkna Ediciler) raporları bu yöntemi kullanan çalışmalara örnek olarak gösterilebilir. The New Persuaders raporlarında öncelikle McClory'nın yukarıda aktarılan sınıflandırması rehber alınarak yumuşak güç değişkenleri beş alt-endeks içinde saptanmıştır. Tablo 2'de 2012 yılı için saptanan değişkenler ve veri kaynakları aktarılmaktadır. 
Tablo 2: 2012 Y11ı The New Persuaders Raporu'ndaki Değişkenler ve Veri Kaynakları

\begin{tabular}{|c|c|c|}
\hline $\begin{array}{l}\text { Alt } \\
\text { Endeks }\end{array}$ & Değişken & Veri Kaynağı \\
\hline \multirow{10}{*}{ 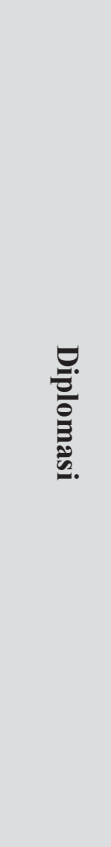 } & $\begin{array}{l}\text { Dış Yardım (Gayri Safi Milli } \\
\text { Hasıla'nın yüzdesi) }\end{array}$ & OECD ve Birleşmiş Milletler Gelişmişlik İstatistikleri \\
\hline & Dış Yardım Toplamı & OECD ve Birleşmiş Milletler Gelişmişlik İstatistikleri \\
\hline & $\begin{array}{l}\text { Vizesiz Seyahat Yapılan Ülke } \\
\text { Sayısı }\end{array}$ & The Henley Visa Restrictions Index 2012 \\
\hline & Kültürel Misyon Sayısı & Hükümet ve Elçiliklerden Alınan Bilgiler \\
\hline & $\begin{array}{l}\text { Ülkedeki Diplomatik Temsilcilik } \\
\text { Sayısı }\end{array}$ & $\begin{array}{l}\text { Değişik Kaynaklar, Sıklıkla Doğrudan Hükümetlerden } \\
\text { Alınan Veriler }\end{array}$ \\
\hline & $\begin{array}{l}\text { Ülke Dışında Açılan Diplomatik } \\
\text { Temsilcilik Sayısı }\end{array}$ & $\begin{array}{l}\text { Dışişleri Bakanlıklarına Ait İnternet Siteleri ve Diğer } \\
\text { Kaynaklar }\end{array}$ \\
\hline & $\begin{array}{l}\text { Uluslararası Örgütler Nezdinde } \\
\text { Görev Yapan Kalıcı Diplomatik } \\
\text { Misyon Sayısı }\end{array}$ & $\begin{array}{l}\text { Dişişleri Bakanlıklarına Ait İnternet Siteleri ve Diğer } \\
\text { Kaynaklar }\end{array}$ \\
\hline & $\begin{array}{l}\text { Üye Olunan Toplam Uluslararası } \\
\text { Örgüt Sayısı }\end{array}$ & CIA World Fact Book 2012 \\
\hline & İmzalanan Çevre Antlaşması Sayısı & CIA World Fact Book 2012 \\
\hline & $\begin{array}{l}\text { Ülkeye Kabul Edilen Mülteci } \\
\text { Sayısı (1000 kişiye düşen sayı) }\end{array}$ & $\begin{array}{l}\text { Statistical Yearbook 2012, BM Mülteciler Yüksek } \\
\text { Komiserliği }\end{array}$ \\
\hline \multirow{11}{*}{ 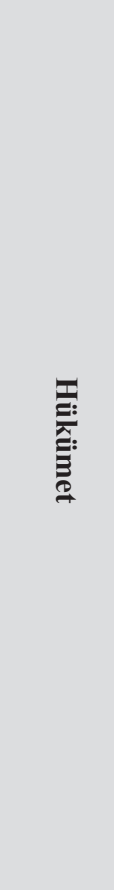 } & $\begin{array}{l}\text { Birleşmiş Milletler İnsani } \\
\text { Gelişmişlik Skoru }\end{array}$ & Birleşmiş Milletler İnsani Gelişmişlik Endeksi \\
\hline & Hükümetin Yararlılığ1 & Dünya Bankası İyi Yönetişim Endeksi \\
\hline & Bireysel Özgürlük & Freedom House Endeksi \\
\hline & Demokratik Kurumlar & The Economist Özgürlük Endeksi \\
\hline & $\begin{array}{l}\text { Ülkedeki Toplam Düşünce } \\
\text { Kuruluşu Sayısı }\end{array}$ & Mc.Gann, J. (2012), The Global Go-To Think Tanks*. \\
\hline & $\begin{array}{l}\text { Ülkedeki Gölge Ekonominin } \\
\text { Büyüklüğü }\end{array}$ & $\begin{array}{l}\text { Buehn, B. \& Schneider, F. "Shadow Economies Around } \\
\text { the World: Novel Insights, Accepted Knowledge, and New } \\
\text { Estimates", International Tax and Public Finance, Cilt: 19, } \\
\text { Say1: 1, 2012, ss. 139-171. }\end{array}$ \\
\hline & Toplumdaki Şiddet & Birleşmiş Milletler Cinayet İstatistikleri \\
\hline & Hükümetin Hesap Verebilirliği & Dünya Bankası Söz Hakkı ve Hesap Verebilirlik Endeksi \\
\hline & $\begin{array}{l}\text { İnfaz Edilen Ölüm Cezası Sayısı } \\
\text { (Geçen Y11 İçinde) }\end{array}$ & Değişik Kaynaklar \\
\hline & Hükümete Güven & Dünya Ekonomik Forumu Hükümete Güven Endeksi \\
\hline & Gelir Dağılımındaki Adaletsizlik & Dünya Bankası \\
\hline
\end{tabular}

* İlgili raporun tam metni için bkz. http://repository.upenn.edu/cgi/viewcontent.cgi?article= 1006\&context= think_ tanks (Erişim Tarihi 6 Şubat 2014). 


\begin{tabular}{|c|c|c|}
\hline \multirow{12}{*}{ 突: } & $\begin{array}{l}\text { Ülkeyi Ziyaret Eden Toplam Turist } \\
\text { Sayısı }\end{array}$ & Birleşmiş Milletler Dünya Turizm Örgütü \\
\hline & $\begin{array}{l}\text { Ülkeyi Ziyaret Eden Turistlerin } \\
\text { Dolar Cinsinden Ortalama Harcama } \\
\text { Miktarı }\end{array}$ & Birleşmiş Milletler Dünya Turizm Örgütü \\
\hline & $\begin{array}{l}\text { Devlet Medyasının Takip Edilme } \\
\text { Düzeyi }\end{array}$ & Monocle Araştırması, Değişik Kaynaklar \\
\hline & Ülkedeki Yabancı Muhabir Sayısı & Press Association ve Diğer Kaynaklar \\
\hline & Anadilin Küresel Gücü & $\begin{array}{l}\text { Weber, G., "Top Languages: the World's } 10 \text { Most Influential } \\
\text { Languages", Language Monthly, Cilt: 3, 12-18, } 1997 .\end{array}$ \\
\hline & $\begin{array}{l}\text { Önceki Yaz ve Kış } \\
\text { Olimpiyatlarında Kazanılan Altın } \\
\text { Madalya Sayısı }\end{array}$ & Uluslararası Olimpiyat Komitesi Veritabanı \\
\hline & $\begin{array}{l}\text { Ülkenin Müzik Marketinin Küresel } \\
\text { Sıralamadaki Yeri }\end{array}$ & $\begin{array}{l}\text { Recording Industry in Numbers 2012, Uluslararas1 Ses } \\
\text { Endüstrisi Federasyonu Verileri }\end{array}$ \\
\hline & $\begin{array}{l}\text { Yabancı Ülkede Satışlarda 1. Sıraya } \\
\text { Yükselmiş Ülke Menşeli Albüm } \\
\text { Sayısı }\end{array}$ & $\begin{array}{l}\text { Recording Industry in Numbers 2012, Uluslararas1 Ses } \\
\text { Endüstrisi Federasyonu Verileri }\end{array}$ \\
\hline & $\begin{array}{l}\text { Dünyanın En Çok Ziyaret Edilen } \\
100 \text { Sanat Müzesine Yıllık Katılım } \\
\text { Sayısı }\end{array}$ & $\begin{array}{l}\text { "Exhibition and Museum Attendance Figures 2010", } \\
\text { The Art Newspaper, Say1: 223, Nisan 2011, s. } 24 .\end{array}$ \\
\hline & $\begin{array}{l}\text { UNESCO Dünya Mirası Listesi'ne } \\
\text { Giren Kültürel ve Doğal Varlık } \\
\text { Sayısı }\end{array}$ & $\begin{array}{l}\text { UNESCO Dünya Mirası Listesi, } \\
<\text { http://whc.unesco.org/en/list/> }\end{array}$ \\
\hline & $\begin{array}{l}\text { FIFA (Uluslararası Futbol } \\
\text { Federasyonları Birliği) Listesinde } \\
\text { Ülke Derecesi }\end{array}$ & FIFA Dünya Sıralaması, 21 Ekim 2012 \\
\hline & $\begin{array}{l}\text { Cannes, Toronto ve Sundance Film } \\
\text { Festivallerine Kabul Edilen Toplam } \\
\text { Film Sayısı }\end{array}$ & Değişik Kaynaklar \\
\hline \multirow{4}{*}{ 四 } & İlk ve Ortaöğretim Kalitesi & OECD Verileri \\
\hline & Üniversitelerin Kalitesi & Times Higher Education Verileri \\
\hline & $\begin{array}{l}\text { Ülkede Okuyan Yabancı Öğrenci } \\
\text { Sayısı }\end{array}$ & UNESCO Verileri \\
\hline & $\begin{array}{l}\text { Akademik Dergilerde Basılan } \\
\text { Makale Sayısı }\end{array}$ & Thomson Reuters Verileri \\
\hline \multirow{6}{*}{ 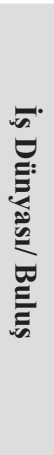 } & $\begin{array}{l}\text { Sahip Olunan Uluslararası Patent } \\
\text { Say1s1 }\end{array}$ & Dünya Fikri Mülkiyet Örgütü \\
\hline & İş Dünyasının Rekabet Edebilirliği & $\begin{array}{l}\text { Schwab, K. Global Competitiveness Report 2011-12, } \\
\text { Cenova: World Economic Forum, } 2011 .\end{array}$ \\
\hline & Yolsuzluk Seviyesi & Uluslararası Şeffaflık Örgütü Verileri \\
\hline & Buluş & $\begin{array}{l}\text { Boston Consulting Group ve National Association of } \\
\text { Manufacturers Verileri }\end{array}$ \\
\hline & $\begin{array}{l}\text { Doğrudan Yabancı Yatırımın } \\
\text { Gayrisafi Sabit Sermaye İçindeki } \\
\text { Yüzdesi }\end{array}$ & $\begin{array}{l}\text { Birleşmiş Milletler Ticaret ve Kalkınma Konferansı } \\
\text { İstatistikleri }\end{array}$ \\
\hline & İnternet Kullanıcı Yüzdesi & CIA World Factbook 2011 Verileri \\
\hline
\end{tabular}

Kaynak: Jonathan McClory, “The New Persuaders III - A 2012 Global Ranking of Soft Power”, Institute for Government, http://www.instituteforgovernment.org.uk/sites/default/files/publications/The\%20new\%20persu aders\%20 III_0.pdf(Erişim Tarihi 6 Şubat 2014), s.17-22. 
Hızlı Büyüyen Pazarlar Yumuşak Güç Endeksi'ne benzer bir biçimde, The New Persuaders endekslerinde de veri kaynağı olarak hükümetlerarası/ulus üstü örgüt, hükümetdışı uluslararası örgüt, meslek örgütü, danışmanlık şirketi, sivil toplum örgütü, gazete ve dergi, haber ajansı, ulusal düzeyde resmi kurum, makale ve kitap kullanılmıştır.

The New Persuders raporlarında, oluşturulan nicel veri sepetine ek olarak kamuoyu araştırmalarına da dayanılmıştır. Tablo 3'te görüldüğü gibi, yine yumuşak gücü ölçme iddiasıyla belirlenen birkaç değişken hakkında kamuoyu araştırmalarına gidilmiş, devletlerin toplam yumuşak güç skorlarının \%70'i Tablo 2'deki veri setlerine, \%30'u ise Tablo 3'teki kamuoyu anketi sonuçlarına göre belirlenmiştir. ${ }^{55}$ Böylelikle yalnızca nicel verilere dayanan yumuşak güç ölçüm denemelerinin yöntemsel yanlışının düzeltilebileceği savlanmıştır.

Tablo 3: 2012 Y11ı The New Persuaders Raporu'ndaki Öznel Panel Kategorileri

\begin{tabular}{|l|l|}
\hline Değişken & Veri Kaynağı \\
\hline Kültürel Ürün & Kamuoyu Anketi \\
\hline Mutfak & Kamuoyu Anketi \\
\hline Yumuşak Güç İkonları & Kamuoyu Anketi \\
\hline Devletin Milli Havayolu Şirketinin Kalitesi & Kamuoyu Anketi \\
\hline Küresel Liderlik & Kamuoyu Anketi \\
\hline Ülkedeki Mimari Altyapının Kalitesi & Kamuoyu Anketi \\
\hline Ülkenin Ticari Markalarının Kalitesi & Kamuoyu Anketi \\
\hline
\end{tabular}

Kaynak: Jonathan McClory, “The New Persuaders III - A 2012 Global Ranking of Soft Power”, Institute for Government Resmi İnternet Sitesi, http://www.instituteforgovernment.org.uk/sites/default/files/publications /The\%20 new\%20persuaders\%20III_0.pdf (Erişim Tarihi 6 Şubat 2014), s.22-23.

\section{Yumuşak Güç Ölçüm Denemelerinin Sınırlılıkları}

Yumuşak gücün ölçümü konusunda yukarıda aktarılan üç yöntem denemesi, önemli sinırlılıklara sahiptir. Bu sınırlılıklar üç başlık altında toplanabilir: (1) Anket sorularının ve endeks değişkenlerinin seçimindeki yönlendiricilik ve cazibenin varlığının saptanabilirliği sorunu (2) Endeks değişkenlerinin ağırlıkların saptanmasında ve veri kaynaklarının seçimindeki keyfiyet, (3) Gücün yarattığı cazibe ile hedef aktörün dış politika çıktıları arasındaki nedensellik bağının saptanmasındaki yetersizlik.

\section{Yönlendiricilik ve Cazibenin Varı̆̆ının Saptanabilirliği Sorunu}

Yumuşak gücü ölçmeyi hedefleyen kamuoyu anketlerindeki bazı soruların yönlendirici olduğu dikkat çekmektedir. Örneğin Pew'in 2012 tarihli anket çalışmasının 58. sorusu şöyledir: "Görüşünüze en yakın yanıt hangisidir? ABD önderliğindeki terörizmle savaş operasyonlarını destekliyorum/ $\mathrm{ABD}$ önderliğindeki terörizmle savaş operasyonlarına karşııım." ${ }^{56} \mathrm{ABD}$ operasyonlarının temel amacının terörizmi ortadan kaldırmak olduğu varsayımı ile hazırlanan bu soruya verilecek yanıtlarda terörizm karşıtlı̆̆ı ile ABD’nin operasyon biçimine yönelik karşıtlık ayrıştırılmamakta, terörizme

55 Jonathan McClory, “The New Persuaders III”, s.9.

56 "Pew Research Center", s.27. 
karşı olan birinin ABD’nin operasyonunu desteklemeye yönlendirildiği açılkça görülmektedir. Aynı anketin sadece Mısır'da sorulan 82. sorusu bu duruma bir diğer örnek oluşturmaktadır. Soru şöyledir: “Bazıları, ülkemizde yaşanan protestoların Batılı güçlerin Mısır’ı istikrarsızlaştırmak için yapmış oldukları girişimlerin sonucu olduğunu söylüyor. Diğerleri protestoların ülkemizdeki politik durumdan memnuniyetsizliğin bir sonucu olduğunu söylüyor. Hangi görüş size daha yakındır?” Böyle bir formülleştirme, protestoları iki nedene indirgemekte, iki neden arasındaki bağlantıyı ya da üçüncü bir nedenin varlığını dışlamakta ve yönlendirici olmaktadır.

Benzer metodolojik sorunlar, cazibenin varlığının saptanabilirliği noktasında da söz konusudur. Örneğin, 2012 tarihli Pew anketinin 29. sorusu dünyanın en büyük ekonomik gücünün hangi ülke olduğu ile ilgilidir. ${ }^{57}$ Oysa bu soruya verilecek hiçbir cevap, cazibenin varlığının kanıtlanması konusunda anlamlı veri oluşturamaz. Bir başka ifadeyle, 29. sorudan birinci çıacak ülkenin otomatik olarak potansiyel yumuşak gücünün en fazla olduğu söylenemez. Çünkü yumuşak güç açısından, kamuoyu araştırmasına konu olan devletin ekonomik gücünün artması ile ilgili hedef kitle algısı değil, bu algı oluşumunun hangi bağlamda yorumlandığı önemlidir. Bu çerçevede örneğin bir aktörün ekonomik gücünün artmasının sömürü ilişkisinin bir sonucu olarak algılanması, o toplumda o aktörün potansiyel yumuşak gücü azaltıcı bir faktöre de dönüşebilir.

Sonuç olarak hedef kitlede cazibenin varlı̆ğının saptanabilirliği konusu, yöntemsel sorunlara ek olarak yapısal bir sorunla da karşı karşıyadır. Çünkü hedef topluluk üzerinde yapılan kamuoyu anketleri ile ölçülmeye çalışan cazibe, yumuşak güç algısının durumsallığı ve kişiselliği nedenleriyle kümülatif bir biçimde çözümlenmeye uygun veri setleri oluşturmamaktadır. Yalnızca kamuoyu araştırmalarına dayanan denemelere örnek olarak verilebilecek Türkiye Ekonomik ve Sosyal Etütler Vakfi'nın (TESEV) “Ortadoğu'da Türkiye Algısı” anketinde ${ }^{58}$ Ortadoğu halklarına sorulan Türk dizisi izlenip izlenilmediği sorusu, bu çerçevede değerlendirilebilir. Üzerinde anket uygulanan kitlenin Türk dizilerini izleme oranları ile Türkiye’nin cazibe düzeyi arasında genel geçer bir bağlantı kurmak mümkün gözükmemektedir. Ayrıca kişi düzeyinde dizinin ürettiği cazibenin varlığı saptansa dahi, bu cazibenin kişisel düzeyde dizinin başrol oyuncusuna $\mathrm{ml}$, senaryosuna $\mathrm{m}$, kişinin ülke kültürü olarak tanımladığı yapıya mı, dizinin menşeini oluşturan devlete mi yönelik olduğu belirlenememektedir. ${ }^{59}$

Nicel verilere dayanma iddiasındaki endeksleme çalışmalarında da cazibenin varlı̆̆ının saptanabilirliği sorunludur. Bu duruma bağlı olarak endeks değişkenlerinin keyfi bir biçimde belirlenme sorunu ortaya çıkmaktadır. Örneğin Hızlı Büyüyen Pazarlar Yumuşak Güç Endeksi’nde ülkede yaşayan göçmen sayısının bir yumuşak güç faktörü olarak tanımlandığı görülmektedir. Bir devletin çok göç alması ilk bakışta söz konusu devletin yaşamak için tercih edilebilir olduğunun bir göstergesi olarak yorumlanmaya uygun olsa da, bu yorum her zaman gerçeği yansıtmayabilir. Örneğin 2012 yılı Birleşmiş Milletler Mülteciler Yüksek Komiserliği verilerine göre Suriye, 476.500 kişi ile en

57 Ibid, s.12.

58 2009-2013 tarihleri arasında yapılan TESEV'in “Ortadoğu’da Türkiye Algısı” araştırmalarına TESEV'in internet sitesinden ulaşılabilmektedir. Bkz. http://www.tesev.org.tr/ (Erişim Tarihi 14 Nisan 2014).

59 Dönemin başbakanı Recep Tayyip Erdoğan’ın, Türkiye'nin yurtdışında en çok izlenen televizyon dizilerinden "Muhteşem Yüzyıl” ile ilgili söylediği sözler bu bağlamda ilginç bir örnek oluşturmaktadır. Erdoğan, söz konusu dizi ile ilgili olarak "o dizilerin yönetmenlerini de o televizyonun sahiplerini de milletimizin huzurunda kınıorum. Ve bu konuda da ilgilileri uyarmamıza rağmen yargının da gerekli kararı vermesini bekliyorum. Böyle bir anlayış olamaz. $\mathrm{Bu}$ milletin değerleriyle oynamaya, milletçe gereken dersin, milletçe gereken cevabın hukuk içinde verilmesi gerekir." ifadesini kullanmıştır. Bkz. "Başbakan Erdoğan'dan Muhteşem Yüzyıl’a Ağır Eleştiri”, Hürriyet, 25 Kasım 2012, http:// www.hurriyet.com.tr/gundem/22009998.asp (Erişim Tarihi 21 Nisan 2014). Bu durumda Muhteşem Yüzyıl dizisinin hedef topluluklarda büyük ilgi oluşturması, Türkiye ile bağlantılı hangi unsurun cazibesinin artışı olarak yorumlanabilir sorusu cevap beklemektedir. 
çok dış göç alan devletler arasında beşinci sırada yer almıştır. Benzer bir şekilde 2012 yılı içinde Pakistan 1.638.500 kişilik bir göç hareketine ev sahipliği yapmış, küresel ölçekte açık ara en fazla göç alan devlet olmuştur. ${ }^{60} \mathrm{Bu}$ rakamlar, endekse göre Suriye'nin ve Pakistan' in cazibe göstergeleri olarak yorumlanıp, yumuşak güç bağlamında bir veri seti haline dönüş̧ecektir. Oysa bu büyük nüfus hareketleri, Pakistan ve Suriye'nin cazibesine dayanan isteğe bağlı göç hareketleri değil, büyük ölçüde bölgede yaşanan istikrarsızlıktan ${ }^{61}$ ve çatışma ortamından kaynaklanan zorunlu göç hareketleridir. Aynı dönemde Suriye'den 728.500 kişinin göç etmesi ${ }^{62}$ kabul edilen göçmen sayısı ile kabul eden devletin yumuşak gücü arasındaki ilişkinin sorgulanması konusunda bir başka dayanak olarak değerlendirilebilir.

\section{Endeks Değişkenlerinin Ağırlıkların Saptanmasında ve Veri Kaynaklarının Seçiminde Keyfiyet}

Yumuşak güç ile ilgili endeksleme çalışmalarında, her bir alt endeks değişkenine, ilgili değişkenin toplam değerindeki payını ifade etmek üzere verilen ağırlık katsayıları, yumuşak gücün ölçümü ile ilgili bir diğer eleştiri konusunu oluşturmaktadır. Örneğin Hızlı Büyüyen Pazarlar Yumuşak Güç Endeksi’nde, ülkede yaşayan göçmen sayısı değişkeninin ağırlığı 11 birim iken, ülke dilinin popülerliği 3.75 birim tutulmuştur. Bu durumda, yukarıda aktarıldığı gibi, yumuşak güç ölçütü olarak değerlendirilmesi sorunlu olan bir değişkene, bir de büyük bir oransal üstünlük tanınmıştır. Endeksleme çalışmasında göçmen sayısının ağırlığının neden 11, ülke dilinin popülerliğinin neden 3.75 birim olarak saptandığıyla ilgili hiçbir argüman ileri sürülmemekte, bu durum da değişken ağırlıklarının saptanmasında bir keyfiyet olduğu tezini doğrulamaktadır. Benzer bir biçimde The New Persuaders Raporu'ndaki değişken ağılıklarının eşit tutulmasını haklı kılacak hiçbir argüman çalışmada yer almamaktadır. Katsayıların saptanmasında hangi nesnel ölçütlerin olduğu, ya da bu konuda nesnel ölçüt oluşturabilmenin mümkün olup olmadığı soruları yanıt beklemektedir.

Keyfiyet eleştirisi veri kaynaklarının seçimi noktasında da sürdürülebilmektedir. Örneğin Hızlı Büyüyen Pazarlar Yumuşak Güç Endeksi’nde güvenilirliği oldukça tartışmalı olan wikipedia internet sitesi bile veri elde etme sürecinde kaynak olarak gösterilmiştir. Bazı değişkenlerde veri kaynağının "değişik kaynaklar” biçiminde aktarılması da veri kaynaklarının seçiminde nesnelliği aşındırıcı bir keyfiyetin varlığını kanıtlamaktadır.

\section{Cazibe-Dış Politika Çıktısı Arasındaki Nedensellik Bağının Saptanmasındaki Yetersizlik}

Yukarıda aktarıldığı gibi, anket sorularının, endeks değişkenlerinin, değişken ağırlık katsayılarının ve kaynakların belirlenmesindeki keyfiyet; yumuşak güç ölçüm denemelerinin önemli eksikliklerini oluşturmaktadır. Tüm bu eksiklikler bir kenara bırakılsa dahi, tanımı gereği yumuşak gücün varlığının ispatı, gücün yarattığı cazibe ile hedef aktörün dış politika çıktıları konusundaki nedensellik bağının saptanması ile mümkündür. Ancak söz konusu endeksler, bu konuda da hiçbir veri ortaya koyamamaktadır. $\mathrm{Bu}$ durumun anket yahut endeksleme çalışmalarındaki yöntem yanlışlarından mı yahut bu bağlantının ölçümünün imkânsızlığı anlamına gelen yapısal sorunlardan mı kaynaklandığı

60 "UNHCR Global Trends 2012-Displacement the New 21st Century Challange", Birleşmiş Milletler Mülteciler Yüksek Komiserliği, s.14, http://unhcr.org/globaltrendsjune2013/UNHCR\%20GLOBAL\%20TRENDS\% 202012_ V08_ web.pdf (Erişim Tarihi 25 Mart 2014).

61 Pakistan’a yönelen büyük göç hareketi neredeyse tamamen Afganistan kaynaklıdır. Ibid. s.12.

62 Ibid. s.15. 
tartışmalıdır. Bir başka ifadeyle, yukarıda aktarılan ölçme girişimlerindeki hatalar yeni yöntemsel müdahalelerle düzeltilebilir midir, yoksa yumuşak gücün ölçümü gerçekten imkânsız mıdır sorusu, anlamlı bir cevap aramaktadır.

Nye 2006 yılında yayınladığı bir makalede, cazibenin genel geçerliği ve cazibe-dış politika çıktısı arasındaki nedensellik bağı konularındaki saptamaların zaaflarını Türkiye örneği üzerinden şu şekilde açıklamıştır:

Avrupa Birliği ülkeleri, diğer ülkelerin Avrupa Birliği’ne katılım heveslerini, Avrupa'nın yumuşak gücünün bir belirtisi olarak tanımlarlar. Günümüzde Türkiye, insan hakları politikaları ve iç hukuk düzlemlerinde Avrupa Birliği standartlarıyla uyumlu değişiklikler yapmaktadır. Bu değişikliklerin ne kadarı Pazara erişim konusunda ekonomik bir saikle, ne kadarı Avrupa'nın başarılı ekonomik ve politik sisteminin çekiciliğinin etkisiyle yürütülmüştür? Şu açık ki bazı Türkler sert güç saikiyle hareket ederken, diğerleri insan hakları ve ekonomik özgürlük konusunda Avrupa modeline bağlıdır. ${ }^{63}$

Nye’ın örneğinden yola çıkılacak olursa, hedef aktörün (Türkiye’nin) politik çıktılarının (Avrupa Birliği standartlarıyla uyumlu olarak yaptığı değişiklikler) Avrupa’nın cazibesinin ürünü olup olmadığı saptanamaz durumdadır. Oysa Nye’ın yumuşak güç tanımına göre, bu güç kategorisinin varlığından ancak böyle bir bağlantının ispatı halinde söz edilebilirdir. Bir başka ifadeyle, Nye'ın yumuşak gücün bir analiz kategorisi oluşturduğu konusunda sunduğu tek kanıt cazibe mekanizmasıdır, ancak bu mekanizma yumuşak gücün varlığını ispat etme konusunda yetersiz kalmaktadır. ${ }^{64}$ Sonuçta Nye da, yumuşak gücün ölçülemez olduğunu kabullenmiş, ancak bunun yumuşak gücün gerçekliğinin olmadığı biçiminde yorumlanması gerektiğini ifade etmiştir. ${ }^{65}$

Nye gibi The New Persuaders'in yönteminin yaratıcısı McClory de, son tahlilde uyguladığı yöntemin ölçüm konusundaki sınırlılıklarını ifade ederek bu yöntem ile devletlerin yumuşak güçlerinin kesin bir ölçümünün gerçekleştirilmesinin mümkün olmadığını, ancak potansiyellerinin ölçülebileceğini belirtmiştir. Bir başka ifadeyle, McClory, yalnızca nicel verilere dayanan yumuşak güç ölçüm denemelerinden daha doğru bir ölçüm yaptığını iddia etmekle birlikte, yumuşak gücün kesin bir biçimde ölçümünün olanaksızlığını da dolaylı bir biçimde kabul etmiştir. ${ }^{66}$

\section{Sonuç}

Yumuşak güç kavramı son yıllarda akademik ve siyasal düzlemlerde adından söz ettiren bir kavram haline gelmiştir. Eşzamanlı olarak yumuşak güce sahip olmanın uluslararası ilişkiler düzleminde bir başarı ölçütü olarak tanımlanmasına sıklıkla rastlanır olmuştur. Bu kadar yoğun bir biçimde kullanılan ve devletlerin dış politikasında bir başarı ölçütü olarak sunulan bir güç kategorisinin ölçümü, doğal olarak uluslararası ilişkiler çalışmalarını meşgul eden bir konu haline gelmiştir. Bu bağlamda, yumuşak gücün kaynakları konusunda birçok sınıflandırmaya gidilmiş, yumuşak gücün ölçümü ile ilgili farklı yöntemsel denemelere girişilmiştir. Bazı denemeler kamuoyu anketleri yoluyla, bazıları yalnızca nicel veriler kullanarak; bazıları ise bu iki veri kaynağı arasındaki bir senteze ulaşarak yumuşak gücü

63 Joseph S. Nye Jr., “Think Again: Soft Power”, Foreign Policy, 23 Şubat 2006, http://www.foreignpolicy.com / articles/2006/02/22/think_again_soft_power (Erişim Tarihi 26 Mart 2014).

64 Hall, "A Critical", s.197.

65 "Father of 'Soft Power' Gives Keynote Speech in Taipei”, The China Post, 11 Aralik 2013, http://www. chinapost.com. tw/business/company-focus/2013/12/11/395693/Father-of.htm (Erişim Tarihi 11 Nisan 2014).

66 McClory, “The New Persuaders III”, s.5. 
ölçme iddiasını taşımışlar, ancak başarısız olmuşlardır. Başarısızlığın göze çarpan ilk nedeni yapılan metodolojik hatalardır. Ancak ölçüm sorunu, bir metodolojik değişiklik aracıllğııla çözülebilir değildir.

$\mathrm{Bu}$ çalışmanın vardığı sonuç, Nye’’n cazibe mekanizması merkezli olarak tanımladığı yumuşak güç kavramsallaştırmasının ontolojik açıdan sorunlu bir güç kavramsallaştırması olduğudur. Bu durum büyük oranda, yumuşak gücün ölçülmesi oldukça zor hatta kimilerine göre imkânsız nitel unsurları barındırmasından ve güç unsurlarının varlığı ile muhatabın tutum, davranış ve düşüncesindeki değişimler arasındaki nedensellik ilişkisinin ispatlanmasının imkânsızlığından kaynaklanmaktadır. Nitekim Nye’ın yumuşak güç tanımına göre, bu güç kategorisinin varlığından ancak böyle bir nedensellik ilişkisinin ispatı halinde söz edilebilirdir. Oysa Nye'ın da dolaylı olarak kabul ettiği gibi, böyle bir nedensellik ilişkisinin varlığını kanıtlayabilmek mümkün gözükmemektedir.

Yumuşak güç olası kaynaklarının saptanması, yumuşak gücün varlığını kanıtlamamakta, bu nedenle yumuşak gücün unsurlarını sayarak bu gücün varlığı konusunda çıkarımlara ulaşan çalışmalar değer-yüklü olma eleştirileriyle karşılaşmaktadır. Bu bağlamda bu çalışmanın getirdiği öneri, yumuşak güç kavramsallaştırmasının bir analiz kategorisi olarak unutulmasıdır. Çünkü yumuşak gücü bir analiz kategorisi konumunda tutmak, onun varlı̆g konusunda ontolojik bir 1srarı sürdürmek anlamına gelir. Bu ısrar, aynı kavramın eşzamanlı olarak bir pratik kategori işlevini yerine getiriyor olmasının da etkisiyle, kavramı son tahlilde bilim-iktidar ilişkilerinden beslenen bir siyasal propaganda aracına dönüştürür. Bu nedenle yumuşak güç, bir analiz aracı olarak kullanılmaktan ziyade bir “iddia” olarak araştırmanın yalnızca nesnesi haline getirilmelidir. ${ }^{67}$

67 Çalışmanın temel tezine getirilebilecek en anlamlı eleştirilerden biri, endeks kullanımının yarattığı geçerlilik sorunlarının birçoğunun sosyal bilimler alanında hâlihazırda çözülmüş olduğu, yumuşak güç ile ilgili literatürün ise bu gelişmeden yeterince pay al(a)madığıdır. Bir başka ifadeyle sorunun ontolojik değil metodolojik bir sorun olduğudur. Çalışma, bu bağlamda bir tartışmayı başlatmayı da hedeflemektedir. Sorunun bir metodolojik sorundan ibaret olduğunun ispatlanması durumunda, bu zamana kadar yumuşak gücün ölçümü konusunda başarılı endeksleme çalışmaları yapılamamasının ardında yatan, kavramın aynı anda pratik kategori olmasından kaynaklanan nedenler, yeni bir araştırma sorusu olarak karşımıza çıkacaktır. 


\section{Kaynakça}

"About the Paw Research Center", Pew Research Center, http://www.pewresearch.org/about/ (Erişim Tarihi 27 Ocak 2014).

Ball, James, "Infographic: Who is Leading the Arms Race?", The Guardian, 16 Haziran 2013, http://www. theguardian.com/uk/datablog/picture/2013/jun/16/infographic-who-leading-the-arms-race (Erişim Tarihi 25 Ocak 2014).

“Başbakan Erdoğan'dan Muhteşem Yüzyıl’a Ağır Eleştiri”, Hürriyet, 25 Kasım 2012, http://www.hur riyet.com. tr/gundem/22009998.asp (Erişim Tarihi 21 Nisan 2014).

Bayraktar, Zülfikâr, “Türkiye’nin Balkanlar'daki Yumuşak Gücü Türk Kültürü”, Karadeniz Araştırmaları, Sayı 35, Güz 2012, s. 181-189.

Brubaker, Rogers, Ethnicity Without Groups, Cambridge, Harvard University Press, 2004.

Brubaker, Rogers, "In the Name of Nation: Reflections on Nationalism and Patriotism", Citizenship Studies, Cilt 8, Say1 2, Haziran 2004, s. 115-127.

Brubaker, Rogers ve Frederick Cooper, "Beyond 'Identity”, Theory and Society, Cilt: 29, Sayı: 2, 2000, s. 1-47.

Carr, E. H., The Twenty Years' Crisis 1919-1939: an Introduction to the Study of International Relations, Hong Kong, The MacMillan Press, 1981.

"Countries Ranked by Military Strength (2013)", GFP, http://www.globalfirepower.com/countries-listing.asp (Erişim Tarihi 25 Ocak 2014).

"Datasets", Pew Research Center, http://www.pewglobal.org/category/datasets/ (Erişim Tarihi 28 Ocak 2014).

Ding, Sheng, "Analyzing Rising Power from the Perspective of Soft Power: a New Look at China's Rise to the Status Quo Power", Journal of Contemporary China, Cilt 16, Sayı 64, Mart 2010, s. 255-272.

"Father of 'Soft Power' Gives Keynote Speech in Taipei”, The China Post, 11 Aralık 2013, http://www. chinapost. com.tw/business/company-focus/2013/12/11/395693/Father-of.htm (Erişim Tarihi 11 Nisan 2014).

Gill, Bates ve Yanzhong Huang, "Sources and Limits of Chinese 'Soft Power", Survival: Global Politics and Strategy, Cilt 48, Sayı 2, Yaz 2006, s. 17-36.

Gilpin, Robert, War and Change in World Politics, Cambridge, Cambridge University Press, 1999.

Grieco, Joseph M., "Anarchy and the Limits of Cooperation: a Realist Critique of the Newest Liberal Institutionalism", International Organization, Cilt 42, Sayı 3, Yaz 1988, s. 485-507.

Hall, Todd, "An Unclear Attraction: a Critical Examination of Soft Power as an Analytical Category", The Chinese Journal of International Politics, Cilt: 3, Sayı: 2, 2010, s. 189-211.

http://repository.upenn.edu/cgi/viewcontent.cgi?article=1006\&context $=$ think_tanks (Erişim Tarihi 6 Şubat 2014).

http://www.tesev.org.tr/ (Erişim Tarihi 14 Nisan 2014).

"Interview with Rogers Brubaker (University of California: Los Angeles) Conducted by Franziska Meissner", Max Planck Gesellschaft, http://www.mmg.mpg.de/special-output/interviews/interview-with-rogersbrubaker-university-of-california-los-angeles/ (Erişim Tarihi 9 Nisan 2014).

Jen, Stephen L. ve Yllmaz, Fatih, "Hard Power of Nations”, 13 Kasım 2012, http://sljmacro.com/wp-content/ uploads/2012/01/Hard-Power-of-Nations.pdf (Erişim Tarihi 25 Ocak 2014).

Jervis, Robert, "Realism, Neoliberalism, and Cooperation: Understanding the Debate", International Security, Cilt 24, Sayı 1, Yaz 1999, s. 42-63.

Johnson, Joe, “How Does Public Diplomacy Measure Up?”, Foreign Service Journal, Ekim 2006, s. 44.

Kemal Kirişçi, “'Yumuşak Güç' Aracı Olarak Daha Dostça Bir Şengen Vize Sistemi: Türkiye'nin Deneyimi”, Uluslararası İlişkiler, Cilt 4, Sayı 13, Bahar 2007, s. 27-56.

Lam, Peng Er, “Japan's Quest for 'Soft Power': Attraction and Limitation”, East Asia, Cilt 24, Sayı 4, Aralık 2007, s. 349-363. 
Leheny, David, “A Narrow Place to Crooss Swords”, Peter Katzenstein ve Takashi Shiraishi (der.), Beyond Japan, Ithaca: Cornell University Press, 2006, s. 211-233.

Li, Mingjiang, "Soft Power: Nurture or Nature", Mingjiang Li (der.), Soft Power - China's Emerging Strategy in International Politics, Plymouth, Lexington Books, 2009, s. 1-24.

McClory, Jonathan, "The New Persuaders III - A 2012 Global Ranking of Soft Power”, Institute for Government, http://www.instituteforgovernment.org.uk/sites/default/files/publications/The\%20new $\% 20$ persuaders\%20III_0.pdf (Erişim Tarihi 6 Şubat 2014).

McClory, Jonathan, “The New Persuaders: an International Ranking of Soft Power”, Institute for Government, 2010, http://www.instituteforgovernment.org.uk/sites/default/files/publications/The\%20new\%20 persua ders_0.pdf (Erişim Tarihi 26 Kasım 2013).

Melissen, Jan, “The New Public Diplomacy: between Theory and Practice”, Jan Melissen (der.), The New Public Diplomacy - Soft Power in International Relations, New York, Pallgrave McMillan, 2005, s. 3-28.

Moore, Adam, "Rethinking Scale as a Geographical Category: from Analysis to Practice", Progress in Human Geography, Cilt: 32, Say1: 2, s. 203-225.

Morgenthau, Hans J., Politics among Nations - the Struggle for Power and Peace, New York, Alfred A. Knopf, 1949.

Naoyuki, Agawa, "Japon Does Soft Power - Strategy and Effectiveness of its Public Diplomacy in the United States", Watanabe Yasushi ve David L. McConnell (der.), Soft Power Superpowers - Cultural and National Assets of Japan and the United States, New York, M.E. Sharpe, 2008, s. 224-245.

Nye Jr., Joseph S., Amerikan Gücünün Paradoksu, çev. Gürol Koca, İstanbul, Literatür Yayınları, 2003.

Nye Jr., Joseph S., Bound to Lead: The Changing Nature of American Power, New York, Basic Books, 1991.

Nye Jr., Joseph S., "Public Diplomacy and Soft Power", The Annals of the American Academy of Political and Social Science, Cilt 616, Say1 1, Mart 2008, s. 94-109.

Nye Jr, Joseph S., Soft Power - the Means to Success in World Politics, New York, Public Affairs, 2004.

Nye Jr., Joseph S., “Think Again: Soft Power”, Foreign Policy, 23 Şubat 2006, http://www.foreignpolicy.com / articles/2006/02/22/think_again_soft_power(Erişim Tarihi 26 Mart 2014).

Oğuzlu, Tarık, “On power”, SEPAM Policy Brief, Sayı 5, Temmuz 2014, s. 1-13.

Oğuzlu, Tarık, "Soft Power in Turkish Foreign Policy", Australian Journal of International Affairs, Cilt 61, Sayı 1, Mart 2007, s. 81-97.

Oğuzlu, Tarık, "Soft Power: the Concept and Its Relevancy", Bilgesam Analysis, Say1 1125, 7 Nisan 2014, s. 1-3.

Oktay, Emel G., "NATO’nun Dönüşümü ve Kamu Diplomasisi'nin Artan Rolü”, Uluslararast İlişkiler, Cilt 9, Sayı 34, Yaz 2012, s. 125-150.

Otmazgin, Nissim Kadosh, Contesting Soft Power: Japonese Popular Culture in East and Southeast Asia, International Relations of the Asia-Pacific, Cilt 8, Sayı 1, 2008, s. 73-101.

"Pew Research Center Global Attitudes Project Spring 2012 Questionnaire", Pew Research Center, http://www. pewglobal.org/category/datasets/?download=27361 (Erişim Tarihi 28 Ocak 2014).

“Rapid Growing Markets Soft Power Index Spring 2012”, Ernste Young, http://emergingmarkets.ey.com/wpcontent/uploads/downloads/2012/05/TBF-606-Emerging-markets-soft-power-index-2012_LR.pdf (Erişim Tarihi 4 Şubat 2014), s. 4-22.

Simard, Jean François ve Pierre C. Pahlavi, "Measuring the Effects of Soft Power, Vanguard Magazine, Mayıs/ Haziran 2009, http://vanguardcanada.com/measuring-the-effects-of-soft-power/ (Erişim Tarihi 25 Ocak 2014).

Singer, J. David et al., "Capability, Distribution, Uncertainty and Major Power War, 1980-1965, Bruce Russett (der.), Peace, War, and Numbers, Beverly Hills, Sage, 1972, s. 19-48.

Song, Tingshan ve Shanshan Chen, "Construction and Measure of the Evaluation Index System of Regional Soft Power - Taking Shandong Province as an Example, Studies in Sociology of Science, Cilt 3, Say1 4, 2012, s. 85-91. 
“The New Persuaders III", Institute for Government, http://www.instituteforgovernment.org.uk/sites/default/ files/publications/The\%20new\%20persuaders\%20III 0.pdf (Erişim Tarihi 27 Ocak 2014).

Treverton, Gregory F. ve Seth G. Jones, Measuring National Power, Santa Monica, Rand Corporation, 2005.

"UNHCR Global Trends 2012 - Displacement the New 21st Century Challange", Birleşmiş Milletler Mülteciler Yüksek Komiserliği, http://unhcr.org/globaltrendsjune2013/UNHCR\%20GLOBAL\%20TRENDS\%20 2012_V08_web.pdf (Erişim Tarihi 25 Mart 2014).

Wang, Yiwei, "Public Diplomacy and the Rise of Chinese Soft Power", Annals of the American Academy of Political and Social Science, Cilt 616, Mart 2008, s. 257-273.

Yapııı, Utku, Sovyet Sonrası Coğrafyada Devlet ve Milliyetçilik, Ankara, Tan Yayınları, 2011.

Yasushi, Watanabe ve David L. McConnell (der.), Soft Power Superpowers - Cultural and National Assets of Japan and the United States, New York, M. E. Sharpe, 2008.

Zheng, Denise E., "China's Use of Soft Power in the Developing World", Carola McGiffert (der.), Chinese Soft Power and Its Implications for the United States, Washington, CSIS, 2009, s. 1-9. 